OPEN ACCESS

Edited by:

Iduna Arduini,

University of Pisa, Italy

Reviewed by:

Baizhao Ren,

Shandong Agricultural University,

China

Ümit Barıs Kutman,

Gebze Technical University, Turkey

Giacomo Tosti,

University of Perugia, Italy

*Correspondence: Meixue Zhou

mzhou@utas.edu.au

Specialty section:

This article was submitted to

Plant Abiotic Stress,

a section of the journal

Frontiers in Plant Science

Received: 28 October 2018

Accepted: 28 January 2019

Published: 12 February 2019

Citation:

Manik SMN, Pengilley G, Dean G, Field B, Shabala S and Zhou M (2019) Soil and Crop Management Practices to Minimize the Impact

of Waterlogging on Crop Productivity.

Front. Plant Sci. 10:140.

doi: 10.3389/fpls.2019.00140

\section{Soil and Crop Management Practices to Minimize the Impact of Waterlogging on Crop Productivity}

\author{
S. M. Nuruzzaman Manik ${ }^{1}$, Georgina Pengilley ${ }^{1}$, Geoffrey Dean ${ }^{1}$, Brian Field ${ }^{1}$, \\ Sergey Shabala ${ }^{1}$ and Meixue Zhou ${ }^{1,2 *}$ \\ ${ }^{1}$ Tasmanian Institute of Agriculture, University of Tasmania, Prospect, TAS, Australia, ${ }^{2}$ Hubei Collaborative Innovation Center \\ for Grain Industry/School of Agriculture, Yangtze University, Jingzhou, China
}

Waterlogging remains a significant constraint to cereal production across the globe in areas with high rainfall and/or poor drainage. Improving tolerance of plants to waterlogging is the most economical way of tackling the problem. However, under severe waterlogging combined agronomic, engineering and genetic solutions will be more effective. A wide range of agronomic and engineering solutions are currently being used by grain growers to reduce losses from waterlogging. In this scoping study, we reviewed the effects of waterlogging on plant growth, and advantages and disadvantages of various agronomic and engineering solutions which are used to mitigate waterlogging damage. Further research should be focused on: cost/benefit analyses of different drainage strategies; understanding the mechanisms of nutrient loss during waterlogging and quantifying the benefits of nutrient application; increasing soil profile de-watering through soil improvement and agronomic strategies; revealing specificity of the interaction between different management practices and environment as well as among management practices; and more importantly, combined genetic, agronomic and engineering strategies for varying environments.

Keywords: agronomic practices, soil engineering, drainage, genetic solutions, waterlogging tolerance

\section{INTRODUCTION}

Waterlogging is one of the focal abiotic stresses, which affects crop growth (Linkemer et al., 1998; Setter and Waters, 2003; Lone et al., 2018). It has become the key constraint to crop production in the temperate high rainfall zone (HRZ) of Australia (Acuña et al., 2011), particularly in regions with duplex soils (Yaduvanshi et al., 2012). Global climate change causes waterlogging events to be more frequent, severe, and unpredictable (Jackson and Colmer, 2005; Intergovernmental Panel on Climate Change [IPCC], 2014). Some currently wet areas will become wetter and prolonged waterlogging will also become more prevalent (Dore, 2005; Intergovernmental Panel on Climate Change [IPCC], 2014). The value of this loss is also signficiant to the Australian grains industry where waterlogging causes an estimated annual production loss of AU\$180 M (Pang et al., 2004) with a greater proportion of this being incurred in Western Australia (Zhang et al., 2006). Waterlogging caused $40-50 \%$ wheat yield reduction in a wet year (Zhou, 2010) resulting in AU $\$ 100$ $\mathrm{M}$ in crop losses (Zhang et al., 2004).

Waterlogging is also a matter of worldwide concern affecting $16 \%$ of the soils in the United States, $10 \%$ of the agricultural lands of Russia and irrigated crop production areas of India, 
Pakistan, Bangladesh, and China (Yaduvanshi et al., 2014; Food and Agriculture Organization [FAO], 2015). Globally, between 10 and 15 million ha of wheat are affected by waterlogging annually causing yield losses of between 20 and 50\% (Hossain and Uddin, 2011). Waterlogging also causes yield losses in other grain crops such as barley, canola, lupins, field peas (Bakker et al., 2007; Romina et al., 2018), lentils and chickpeas (Solaiman et al., 2007).

Appropriate soil and crop management practices improve soil quality and crop productivity, through improved ecological and economical flexibility by reducing the need for additional agricultural land (Setter and Belford, 1990; Tilman et al., 2002; Shaxson and Barber, 2003). Improved soil management can increase infiltration, reduce surface runoff, and additionally improve availability of water and nutrients to plants (Amare et al., 2013; Negusse et al., 2013; Schmidt and Zemadim, 2015; Masunaga and Marques Fong, 2018). Crop management can contribute to higher yields (Soomro et al., 2009; Amare et al., 2013). This review focuses on the impact of waterlogging on soil properties, plant growth and agricultural management practices to mitigate waterlogging. The gaps in current knowledge, technology and farm practices are identified, and recommendations are made for future opportunities to ensure sustainable soil and crop management under waterlogged conditions.

\section{WATERLOGGING EFFECT ON SOIL AND PLANT GROWTH}

Waterlogging impedes the ability of soil to provide an optimum medium for plant growth and alters its physical, chemical, electro-chemical and biological characteristics as summarized in Figure 1 (Pulford and Tabatabai, 1988; Glinski, 2018; Ferronato et al., 2019). This has a significant impact on the development of the root biomass and subsequently on plant overall development (Figure 2) (Ernst, 1990; Pierret et al., 2007; de San Celedonio et al., 2016). Fundamentally, the soil should have optimal water and air content for the proper physiological performance of the all phases of plant growth (Crawford, 1982).

Waterlogging hinders the growth of plants by reducing the dispersal of oxygen through the pore spaces in the soil around the root zone (Drew and Sisworo, 1977; Lee T.G. et al., 2007; Christianson et al., 2010) with the dispersal of oxygen being $320 \mathrm{~K}$ times lower than that in non-submerged soils (Armstrong, 1980; Barrett-Lennard, 2003; Lee T. et al., 2007; Colmer and Greenway, 2011). The plant root needs an adequate supply of oxygen so as to fulfill the water and nutrient requirements of the shoots, and the soil oxygen concentration should be above $10 \%$ where atmospheric molecular oxygen concentration is 21\% (Sojka and Scott, 2002; Brady and Weil, 2008; Colmer and Greenway, 2011; Morales-Olmedo et al., 2015; da Ponte et al., 2019). Under waterlogging conditions, oxygen demand to the root tip and to the rhizosphere is supplied by forming aerenchyma through removal of some cells of the cortex and these remove excess gases from the root and soil (Armstrong, 1980; Colmer and Greenway, 2011). The gas exchange between soil and atmosphere in a well aerated soil is amply rapid to decelerate $\mathrm{O}_{2}$ deficiency and toxicity caused by excess $\mathrm{CO}_{2}$ or other gases such as ethylene and methane (Sojka and Scott, 2002). A number of hydroponic or inert substrate experiments assessed the effect of hypoxia and anoxia on plants in waterlogged conditions, and determined the soil is a vital factor (Morard and Silvestre, 1996; Striker, 2008; Arbona et al., 2009; Bai et al., 2013; Morales-Olmedo et al., 2015). Excessive water content in the soil upon waterlogging decreases $\mathrm{O}_{2}$ diffusion capacity, leading to hypoxic or even anoxic environments that inhibit the activity of nitrifying communities, resulting in depleted soil $\mathrm{N}$ availability that will negatively affect $\mathrm{N}$-dependent crop productivity (Jaiswal and Srivastava, 2018; Nguyen L.T. et al., 2018). Thus, the rate of nitrification is estimated to decrease in response to waterlogging conditions (Reddy and Patrick, 1975; Laanbroek, 1990).

Moreover, decreasing molecular oxygen prompts a sequence of changes in the physico-chemical properties of the soil (Ponnamperuma, 1984). Many of these also change soil chemical and electro chemicals by decreasing redox potential and excess electron changes, such as $\mathrm{Fe}^{3+}$ and $\mathrm{Mn}^{4+}$ to $\mathrm{Fe}^{2+}$ and $\mathrm{Mn}^{2+}$, correspondingly (Ponnamperuma, 1984; Jackson and Colmer, 2005; Singh and Setter, 2017). Thus, solubility of iron and manganese rises to toxic levels, which are potentially damaging to plant roots (Jones and Etherington, 1970; Aldana et al., 2014; Marashi, 2018; Sharma et al., 2018). Apart from the elemental toxicities to the sensitive root tips, increased concentration of secondary metabolites such as phenolics and volatile fatty acids may become injurious in the low-pH rhizosphere (Pang et al., 2007a; Shabala, 2011; Coutinho et al., 2018). pH values of waterlogged soil can be further reduced by the accumulation of volatile organic acids as well as the high concentration of $\mathrm{CO}_{2}$ (Greenway et al., 2006) which reduces root growth (Boru et al., 2003). As mentioned, another potential toxic metabolite found in waterlogged soil is ethylene, which suppresses root expansion growth (Drew and Lynch, 1980; Shabala, 2011). In addition, with the re-introduction of oxygen at the recovery phase, the remaining ethanol in anoxic cells will be transformed into acetaldehyde which may cause cell injuries (Bailey-Serres and Voesenek, 2008). Under abiotic stress conditions, reactive oxygen species (ROS) levels are always elevated compared to pre-stress levels (Miller et al., 2008). Excessive production of various ROS such as superoxide radicals, hydroxyl radicals, hydrogen peroxide, and singlet oxygen found in hypoxia-stressed leaf and root tissues (Blokhina et al., 2003; Sairam et al., 2009; Petrov et al., 2015; Shabala et al., 2016) can also cause severe damage to plants. All of these lead to restricted root growth, reduced tiller number, premature leaf senescence and production of sterile florets thus affecting the grain yield (Collaku and Harrison, 2005; Hossain and Uddin, 2011; Cannarozzi et al., 2018).

Even though the accumulation of phytotoxic compounds requires time, the absence of oxygen alone is enough to change the plant metabolic activities to critical levels (Geigenberger, 2003; Perata et al., 2011). $\mathrm{O}_{2}$ deficiency during waterlogging leads to reduced availability of energy in the roots (Armstrong et al., 1991) and, as a result, energy-dependent processes such as nutrient uptake are inhibited (Setter and Belford, 1990). N deficiency is believed to be the other cause of the suppression of growth under waterlogging (Cannell et al., 1980; 


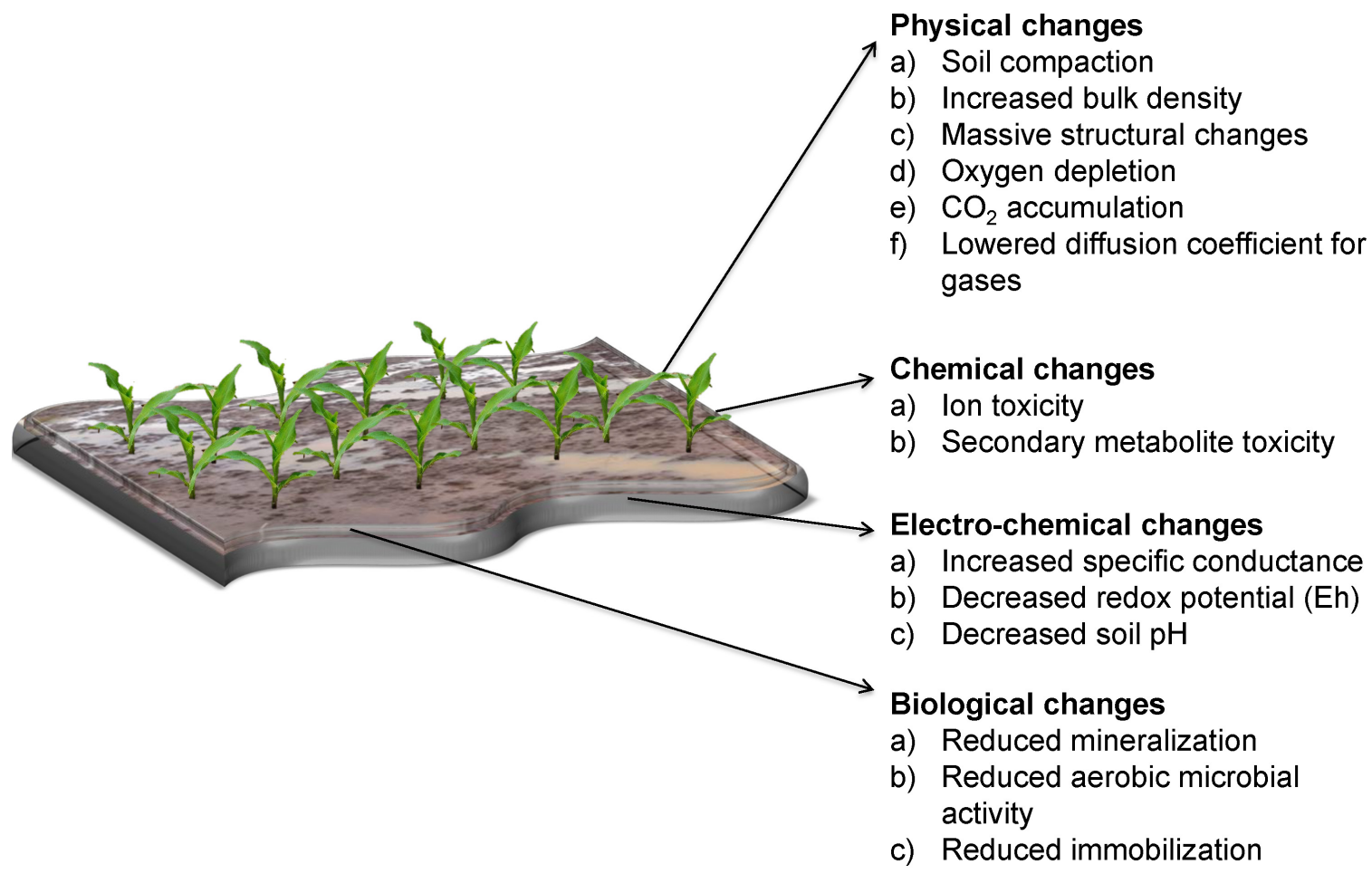

FIGURE 1 | Effects of waterlogging on soil properties.

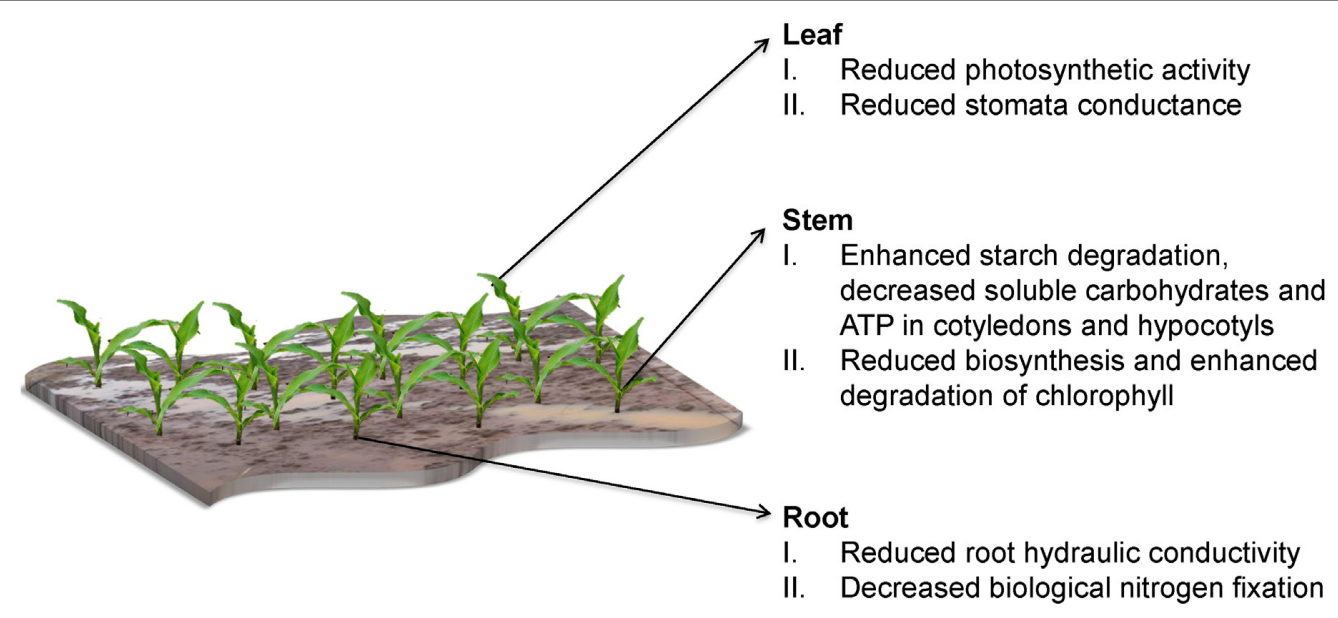

FIGURE 2 | Effects of waterlogging on plant growth.

Robertson et al., 2009; Wollmer et al., 2018). Carbohydrate (the energy reserve) production reduced dramatically during complete submergence or subsequent de-submergence due to reduced photosynthetic rate (Sarkar et al., 2006; Pérez-Jiménez et al., 2018), reduced stomatal conductance, declined root hydraulic conductivity and reduced translocation of photo assimilates (Parent et al., 2008). One of the first plant responses to waterlogging is the reduction in stomata conductance (Folzer et al., 2006), for example, fast stomata closure in barley (Yordanova et al., 2005) and pea (Zhang and Zhang, 1994).
The stomata closure was attributed to abscisic acid (ABA) transport from older to younger leaves or de novo synthesis of this hormone (Zhang and Zhang, 1994). Waterlogging also decreases the leaf chlorophyll content (Malik et al., 2001; Ashraf et al., 2011; Li et al., 2018; Ma et al., 2018). This decrease in chlorophyll directly or indirectly affects the photosynthetic capacity of plants (Azhar et al., 2018; Rasheed et al., 2018; Yu et al., 2019). This decrease in transpiration and photosynthesis is attributed to stomata closure (Ashraf and Arfan, 2005; Tian et al., 2018) which restricts $\mathrm{CO}_{2}$ movement (Jackson and Hall, 1987; 
Malik et al., 2001; Chu et al., 2018). To summarize, waterlogging affects overall plant growth, which leads to a substantial yield loss (Kumar, 2018; Romina et al., 2018; Wollmer et al., 2018).

\section{SOIL MANAGEMENT}

Soil management practices such as drainage, tillage and traffic control can alter soil structure directly or indirectly (Pagliai et al., 2004; Unger et al., 2018). Many of these changes are relatively short term and reversible. Management-induced changes in the quantity and characteristics of soil can also lead to changes in soil structure that are much more persistent. Management practices which are sustainable must maintain the structure of soil, over the long term, in a state that is optimum for a range of processes related to crop production and environmental quality (Bogunovic et al., 2017; Belmonte et al., 2018).

Soil surface biological communities provide critical functions in many ecosystems by controlling infiltration and thus ensure suitable water availability for crop, soil biota, nutrient cycles and vascular vegetation (Chamizo et al., 2016). They increase biodiversity, accelerate soil formation rates, and contribute to the biogeochemical cycling of nutrients by fixing atmospheric carbon (C) and nitrogen (N) (Elbert et al., 2012; Weber and Hill, 2016). Therefore, a key consideration in designing management practices must be targeting the soil surface.

Various soil management practices can mitigate adverse effects of waterlogging stresses. Here, we review some soil management practices emphasizing the system used for waterlogging-prone areas.

\section{Controlled Traffic Farming (CTF)}

Controlled traffic farming (CTF) is a management system to control extensive unsystematic trafficking by farm machinery/vehicles and protect soil structure from indiscriminate change (Hamza and Anderson, 2005). CTF (Figure 3) is a crop production system where the crop region and traffic-lanes are markedly divided (Taylor, 1983; Raper, 2005; Bochtis and Vougioukas, 2008). It creates two distinct zones, the crop region which is non-trafficked and traffic region or non-cropped. Consequently, CTF systems always maintain the crop region unaffected by wheel tracks, whereas the traffic zone develops into a compacted zone for machinery draught efficacy (Taylor, 1992). CTF is differentiated from conventional traffic practices, known as random traffic farming (RTF) by reducing the trafficked area.

Random traffic farming or disorganized traffic causes increases in the soil bulk density resulting in increases in strength limiting soil porosity further leading to soil compaction (Tullberg, 2000; Chen et al., 2010; Rasaily et al., 2012). RTF has an adverse effect on a wide range of soil physical characteristics, including the infiltration and drainage of water, amenability for crop sowing, establishment and nurture, and soil gaseous exchange medium and soil-living organism (Gasso et al., 2013; Gasso et al., 2014). Due to random traffic a large amount of soil is adversely affected resulting in soil degradation issues in Australia (4 million ha), Europe (33 million ha), Asia (10 million ha), Africa
(18 million ha) (Flowers and Lal, 1998; Hamza and Anderson, 2003; Shahrayini et al., 2018).

The advantages of CTF have been well documented. These include reduced incidence of waterlogging, soil compaction, erosion, tillage, water and nutrient losses and thus increased crop yield (Morling, 1982; Raper, 2005; Tullberg et al., 2007; Chamen, 2015). Adoption of CTF by Australian grain growers was 3\% in 2003 (Price, 2004), 15\% in 2006 and 36\% in 2008 (Robertson, 2008). In Australia a minimum of $10 \%$ yield improvement in barley, wheat, and canola across diverse soil types has been noted along with decreases in fuel consumption of machinery due to improved draught on the traffic area (Webb et al., 2004; Li et al., 2007; Robertson et al., 2007; Lorimer, 2008; Davies et al., 2012). In Europe yield of cereal crops (i.e., wheat and barley) increased from 9 to $21 \%$ with CTF compared with RTF (Gasso et al., 2013). Similarly, wheat yield with CTF increased by $6.9 \%$ compared to traditional tillage in China (Qingjie et al., 2009).

\section{Strategic Deep Tillage and Subsoil Manuring}

Strategic deep tillage (SDT) is a single or occasional practice with a deep ripper, rotary, spader, mouldboard plow or disk plow to help sustain the long-standing productivity of the no-till system (Renton and Flower, 2015; Roper et al., 2015; RinconFlorez et al., 2016; Kuhwald et al., 2017; Scanlan and Davies, 2019). Deep tillage or soil cultivation to loosen compact soil layers, particularly the clay subsoil, has been suggested to improve drainage in the subsoil, thus reducing waterlogging (Gardner et al., 1992). The technique may also incorporate slotting of gypsum to reduce sodicity and improve soil structure, which also reduces waterlogging (Crabtree, 1989; McFarlane and Cox, 1992).

Deep ripping loosens hard layers of soil by using sturdy tines to $35-50 \mathrm{~cm}$ depth. It is not suitable for all soils and crops, therefore season, timing, soil type, tine spacing, shallow leading tines, soil moisture content, and working depth are all factors that need to be taken into consideration. The benefit of combined CTF and SDT may last for three seasons but can be as long as ten seasons with average wheat yield increase in Western Australia being $0.6 \mathrm{t} / \mathrm{ha}$ and $0.5 \mathrm{t} / \mathrm{ha}$ at 12 sites and 16 sites, respectively (Davies et al., 2012; Roper et al., 2015). Schneider et al. (2017) conducted a meta-analysis of 1530 yield comparison at 67 experimental sites across Germany, United States, Canada, and India and showed increased yield of greater than $6 \%$ between deep and ordinary tillage systems.

There are, however, several disadvantages of deep ripping including its short-term nature (especially if traffic is not managed to reduce re-compaction), effectiveness in hostile sub-soils, such as acidity, sodicity or subsoil salinity, and its implementation on a large scale (Bakker et al., 2007). In this case, amelioration with gypsum or lime may be helpful to stabilize the soil (Henry et al., 2018; Matosic et al., 2018). Although yield benefit from SDT has been demonstrated, organic matter, texture and soil nutrients distribution within the root zone need appropriate long term agronomic management to maximize the benefit (Roper et al., 2015). 


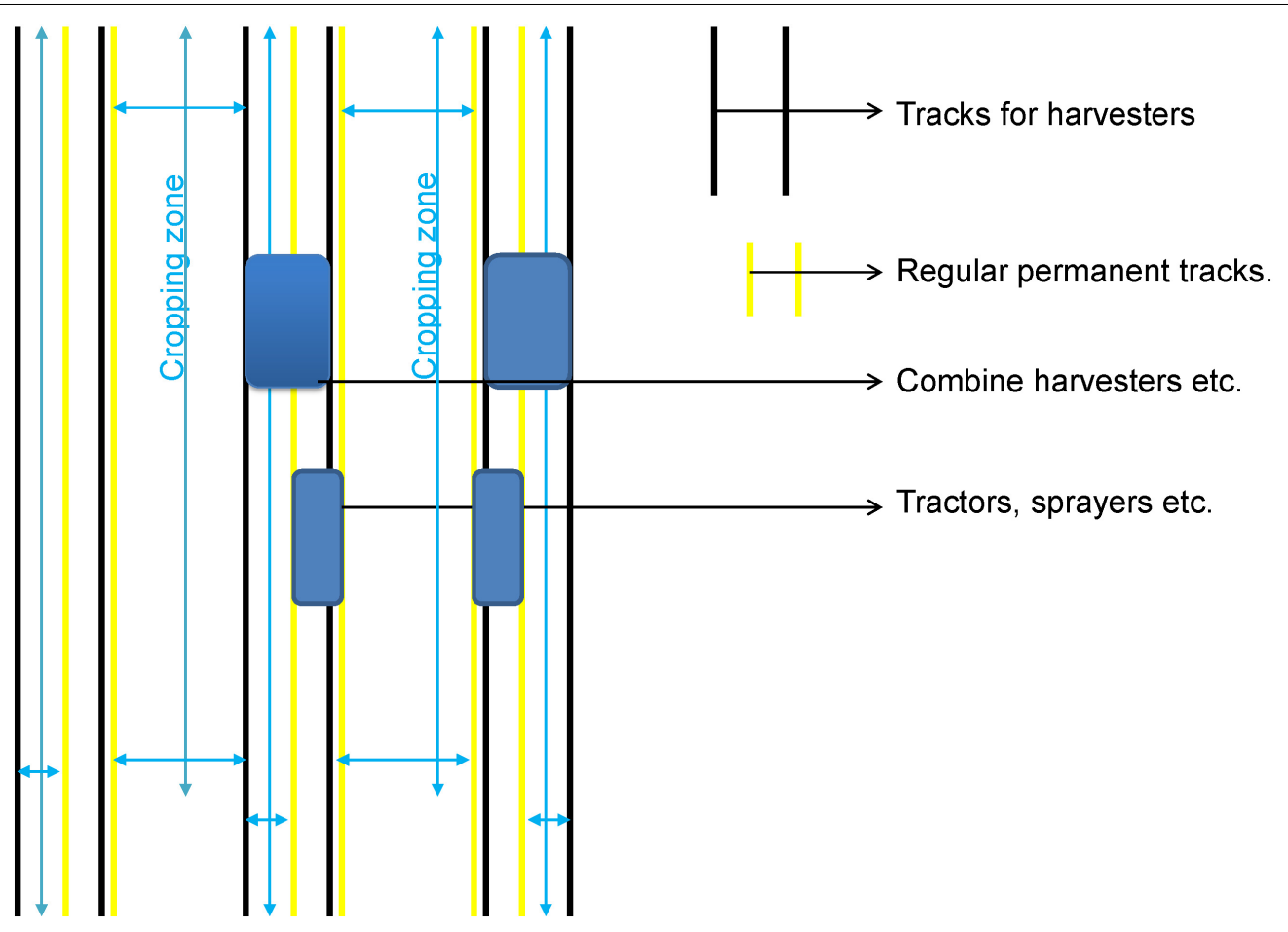

FIGURE 3 | Controlled traffic farming.

Another way of reducing waterlogging is through a similar practice where large volume of organic matter with high $\mathrm{N}$ levels are placed within and above the heavy clay layers. This practice is referred to as sub-soil manuring (Gill et al., 2009; Peries, 2013; Celestina et al., 2018). In south eastern Australia approximately $80 \%$ of the cropping zone of medium annual rainfall $(375-500 \mathrm{~mm})$ and high rainfall $(>500 \mathrm{~mm})$ are affected by subsoil constraints (Grains Research, and Development Corporation [GRDC], 2016). Amelioration of subsoil constraints may be possible by slotting large quantities $(>10 \mathrm{t} / \mathrm{ha})$ of organic matter and other amendments (Sale, 2014; Armstrong et al., 2015). Experiments carried out in Victoria, Australia demonstrated that lucerne pellets and commercial poultry manure can significantly improve soil properties and crop growth as well as yield by improving subsoil structure and supplying $\mathrm{N}$ (Gill et al., 2009, 2012).

The increase in water extraction by roots also provides a greater buffer for subsequent waterlogging events. However, adoption on a commercial scale has remained low due to a combination of high upfront costs (up to $\$ 1200 / \mathrm{ha}$ ) to implement, variable yield responses and logistical constraints such as the limited availability of suitable organic matter sources and access to appropriate machinery (Nicholson, 2016; Armstrong et al., 2017).

\section{Drainage Systems}

Land drainage is one of the main approaches to improve yields per unit of accessible agricultural area (Bos and Boers, 1994; Malano and van Hofwegen, 2006; Singh, 2018b). Reducing soil submergence, salinity control, and making new land accessible for agriculture are the three main objectives of agricultural drainage (Singh and Panda, 2012; Singh, 2018b). However, drainage, an efficient agriculture engineering system to combat waterlogging, has not been given equal importance when compared to irrigation by individual farmers and governmental agencies.

Drainage is used to alleviate waterlogging not only in some parts of Australia (Cox et al., 1994; Milroy et al., 2009), but also world-wide. Various studies, conducted in England, Europe, and North America indicate that drainage can effectively lower the water table and improve crop yields (Cannell and Jackson, 1981; Evans and Fausey, 1999; Bullock and Acreman, 2003; Blann et al., 2009; Smedema et al., 2014; Gramlich et al., 2018). It was also reported to greatly reduce wheat yield losses due to waterlogging in south-western Victoria (Gardner and Flood, 1993; Christy et al., 2015; Feng et al., 2018). Despite the yield losses associated with waterlogging on prone Australian texture-contrast soils, large scale adoption of drainage is still limited in the HRZ (Cox et al., 2005; Rengasamy, 2006; Christy et al., 2015). Various methods have been recommended to mitigate the waterlogging problems, such as surface drainage, subsurface drainage, and mole drains (Muirhead et al., 1996; Misak et al., 1997; Konukcu et al., 2006; Ram et al., 2007; Ritzema et al., 2008; Kazmi et al., 2012; Singh, 2012, 2016; Singh and Panda, 2012).

\section{Surface Drainage}

Surface drainage is defined as the safe removal of excess water through constructed channels from the land surface 
(Ritzema et al., 2008; Ayars and Evans, 2015). Surface drains such as 'spoon-drains,' 'W-drains' and reverse seepage interceptor banks and interceptor drains have been used to alleviate the conditions of waterlogging in south-western Australia (Cox et al., 1994). Surface drainage systems have been shown to be cost effective with cost-benefit ratios being in the range from 1.2 to 3.2 , internal return rates from 20 to $58 \%$, and payback periods from 3 to 9 years (Ritzema et al., 2008). The simplest and cheapest option is to maintain existing surface drains and install extra drains along fence lines or through depressions considering adequate size and proper position. Preventing water flow from upper to lower paddocks with cut-off drains should also be implemented (Palla et al., 2018). However, the success of surface drainage is often limited due to the poor lateral water movement or internal soil drainage properties, which results in poor drainage in the vicinity of the drains (McFarlane and Cox, 1992; Cox and McFarlane, 1995; Saadat et al., 2018). Both surface and subsurface drainage may thus be required to solve these problems.

\section{Raised Bed System}

The use of raised beds (Figure 4) is an important soil management option to improve crop yield, soil structure, and productivity under waterlogged conditions (Hamilton et al., 2000; Bakker et al., 2005b; Hussain et al., 2018). The beds reduce waterlogging and improve the overall soil structure through installing shallow drains or furrows approximately $15-20 \mathrm{~cm}$ wide at regular intervals. These are then used for tractors, and sprayers to control traffic movement over the paddock (control traffic farming) (Collis, 2015). The $2-3 \mathrm{~m}$ wide and $10-30 \mathrm{~cm}$ height bed is formed using soil creating a raised bed allowing water to drain away from the plant root zone and reducing the likelihood of waterlogging damage (Riffkin et al., 2003; Bakker et al., 2007; Gibson, 2014; Ghazouani et al., 2015). Planting on beds also diminishes pesticide applications due to a reduction in fungal and other diseases with improved radiation interception, acquisitive temperature and reduced humidity in the canopy (Alwang et al., 2018).

When seasonal conditions are appropriate, raised beds can significantly increase grain yield under waterlogged conditions compared with crops grown conventionally on flat ground (Bakker et al., 2007; Acuña et al., 2011). In Australia, raised beds are used in irrigated agriculture in New South Wales and north-west Victoria, as well as in cotton growing areas in New South Wales to minimize the impacts of waterlogging (Bakker et al., 2005a; Bakker et al., 2007). The use of raised beds is also prominent in high rainfall areas across Victoria and experiments demonstrated that wheat and barley yield increased by $50 \%$ and $30 \%$, respectively (Collis, 2015), and were proposed for the waterlogged duplex soils of Western Australia (Bakker et al., 2005a; Bakker et al., 2005b), and for the frequently waterlogged arable land across the south-eastern wheat belt of Western Australia (Bakker et al., 2007). Permanent raised beds and furrow systems are also used to manage waterlogging in Mexico (Roth et al., 2005) and coastal lowlands in humid tropical regions in some South Asian countries (Velmurugan et al., 2016), consistently delivering higher returns based on cost-benefit analyses.

While raised beds have had a positive impact on alleviating the effects of waterlogging they also have a number of disadvantages. These include the cost of adapting and modifying machinery, greater difficulty in controlling sowing depth and seed placement on beds, management of drainage water, limited use where the water table is too high, stubble handling and fodder conservation, firefighting and mustering livestock, the possibility of pesticide contamination into waterways and leaching into the water table and inefficiencies of machinery and weed control in furrows (Bakker et al., 2005b; Gibson, 2014). When raised beds were compared with hump and hollow surface drainage in waterlogged pastures at Derrinallum, Victoria it was concluded that the use of raised beds for the growing of pastures for grazing had little to offer the sheep industry (Ward et al., 2007). This poses a significant research question around suitability of raised beds in the many mixed farming systems that operate across the HRZ of Australia.

\section{Subsurface Drainage}

Poor subsurface water movement occurs due to the inability of water to move through soil as a result of heavy soil

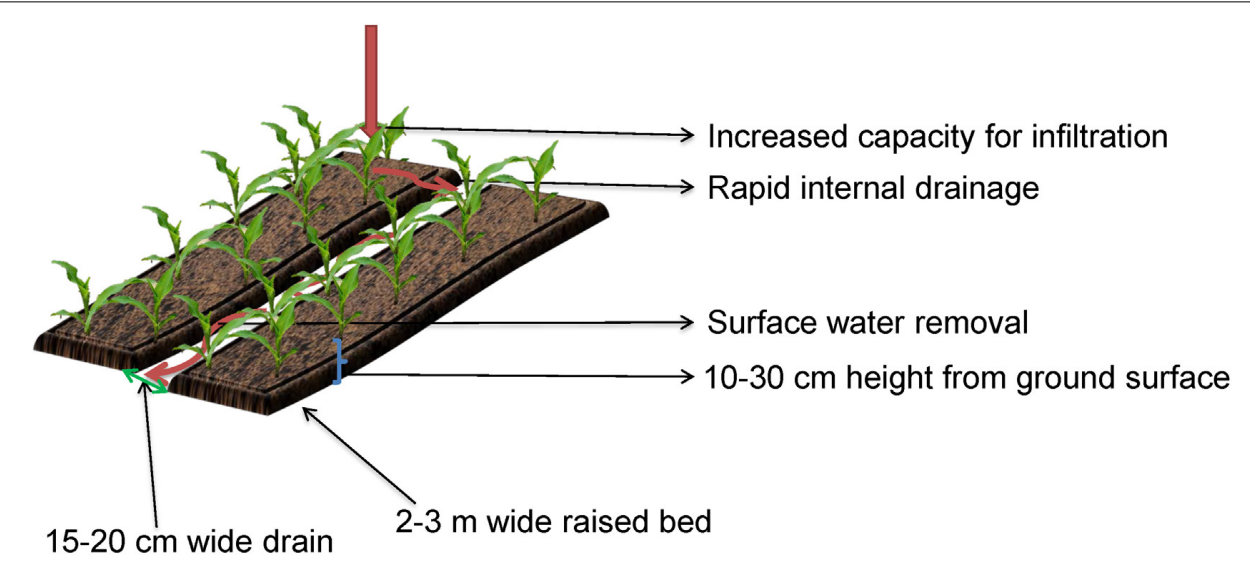

FIGURE 4 | Raised bed cropping system. 
texture, compacted layers and naturally created or induced hard pans as well as water moving downhill from upper slopes or from springs, raising the water table (Ward et al., 2018). Subsurface drainage lowers the water table or perched water and ensures a suitable environment in the root region where waterlogging occurs (Christen et al., 2001; Xian et al., 2017). About 50\% of waterlogged areas in western Europe, $20-35 \%$ of total cultivated land in Europe and North America, $5-10 \%$ in Asia, Australia, and South America, and $0-3 \%$ in Africa have used subsurface drainage measures (Food and Agriculture Organization [FAO], 2002). Subsurface drainage systems consist of open and pipe drains with variable drain depth and spacing (Ritzema et al., 2008). The systems are more effective in areas where the subsoils are sufficiently stable (Gardner et al., 1992) and not exhibiting characteristics of hostile sub-soils such as sodicity.

Subsurface pipe drains are the main forms of subsurface drainage found in the HRZ of Australia (Christen et al., 2001). Usually, the type of drain to be installed depends on topography, soil characteristics and rate of drainage required. There has been successful use of sub-surface drainage in areas of Tasmania, Australia and grain growers are willing to invest in drainage as a long-term solution to waterlogging (Gibson, 2014). This is also supported by a study into the economics of drainage, which indicated that subsurface drainage provided crop growers with the confidence to target high potential yields where the cost benefit was positive (Bastick and Walker, 2000).

Although, subsurface deep drains (depth $>1.75 \mathrm{~m}$ ) are recommended in India (Gupta, 2002), these deep drains can be economically installed only by mechanical construction practices, and the deeper the drain the higher the installation cost (Gupta, 1997). In some parts of Australia, several types of subsurface drainage were found to be unsuccessful because they were expensive and failed to control surface water (McFarlane and Cox, 1992). Managing waterlogging with horizontal tile drainage systems (using a combined drainage system with tube wells plus horizontal drainage systems) is more beneficial in maintaining the water table within the desirable depths (Chandio et al., 2013). In Australia, subsurface drainage such as tile and mole drainage are shown to be particularly useful for irrigated high-value crops such as perennial horticulture, cotton, pasture, sugarcane and perennial pastures for dairying (MacEwan et al., 1992; Christen et al., 2001).

\section{Subsurface Pipe Drains}

Horizontal subsurface (Figure 5) drainage removes excess water from the crop root zone (Tanji, 1990; Teixeira et al., 2018). Below the ground surface, the drainage structure comprises a grid of perforated pipes connected to control the water table. Tile drainage is a form of horizontal subsurface drainage consisting of small pipes of concrete or burnt clay installed at a certain depth below the ground surface (King et al., 2014). Tile drainage is used widely in agricultural areas where subsoil surplus water is a common problem (Williams et al., 2015). To improve the system gravel is usually used above the tile drains as a backfill material in the areas where there is shallow groundwater and heavy soil conditions (Filipović et al., 2014).
Besides water table control, horizontal drainage controls soil salinity in the root zone of the soil by leaching out the concentrated and harmful salt solutions (Christen and Skehan, 2001). This is an established and significantly relevant system for saline land reclamation in Australia and India in irrigation areas where excess soil salinity is the prime limitation in agricultural production (Christen and Skehan, 2001; Prathapar et al., 2018). However, this method may not be suitable for agricultural lands where the top soils are prone to seasonal waterlogging due to poor hydraulic conductivity and the need to find appropriate outfall for drained water (Christen and Skehan, 2001; Food and Agriculture Organization [FAO], 2002; Prathapar et al., 2018; Singh, 2018a).

\section{Vertical Subsurface Drainage}

Vertical drainage (VD) (Figure 6) is used for controlling rising groundwater levels in some parts of Australia such as Burdekin, Kerang, and Shepparton (Christen et al., 2001; Kijne, 2006). Recent results showed that installing VD can reduce the duration of seasonal waterlogging in Bihar, India (Prathapar et al., 2018). Various types of vertical drains have been used to consolidate the soil, such as prefabricated vertical drains (PVDs), sand compaction piles, sand drains, gravel piles and stone columns (Indraratna et al., 2005; Indraratna, 2017). Recently, PVDs have been installed in Brisbane and Ballina in Australia (Indraratna, 2017). The VD system has some advantages over other subsurface drainage systems. For example, VDs are often preferred because of relative low capital cost and the length of open surface drains is less with VD when compared with other types of drainage (Christen et al., 2001). VDs also allow the groundwater level to be lowered to a greater depth than other drainage systems (Kruseman and Ridder, 1990). However, the maintenance and operational costs are higher than horizontal drainage systems as it involves high energy to operate a network of tube wells (Christen et al., 2001; Food and Agriculture Organization [FAO], 2002; Prathapar et al., 2018). The effectiveness of the VD system is demonstrated by the drop in the groundwater level, therefore, the system is more suitable for an area with fluctuating high levels of groundwater.

\section{Mole Drains}

Mole drainage (Figure 7) is another form of subsurface drainage. Its effects on reducing waterlogging have been shown in Victoria, Australia (Frank, 2010; Gibson, 2014). Mole drain systems were found to improve performance in terms of growth parameters, yield attributes and economic parameters of soybean (Glycine max) and wheat (Triticum aestivum) in Madhya Pradesh, India (Dhakad et al., 2018).

Mole drains are a semi-permanent system from a layout and operational point of view and are similar to tile drainage. Although costing less than tile drainage, they do require more maintenance (Tuohy et al., 2016, 2018; Dhakad et al., 2018). This drainage system is generally installed to manage rising groundwater levels and land salinization problems (Robinson et al., 1987; Castanheira and Serralheiro, 2010; Kolekar et al., 2014). Mole drainage relies on closely spaced channels and subsoil cracks to quickly send surplus soil water to the tile or 


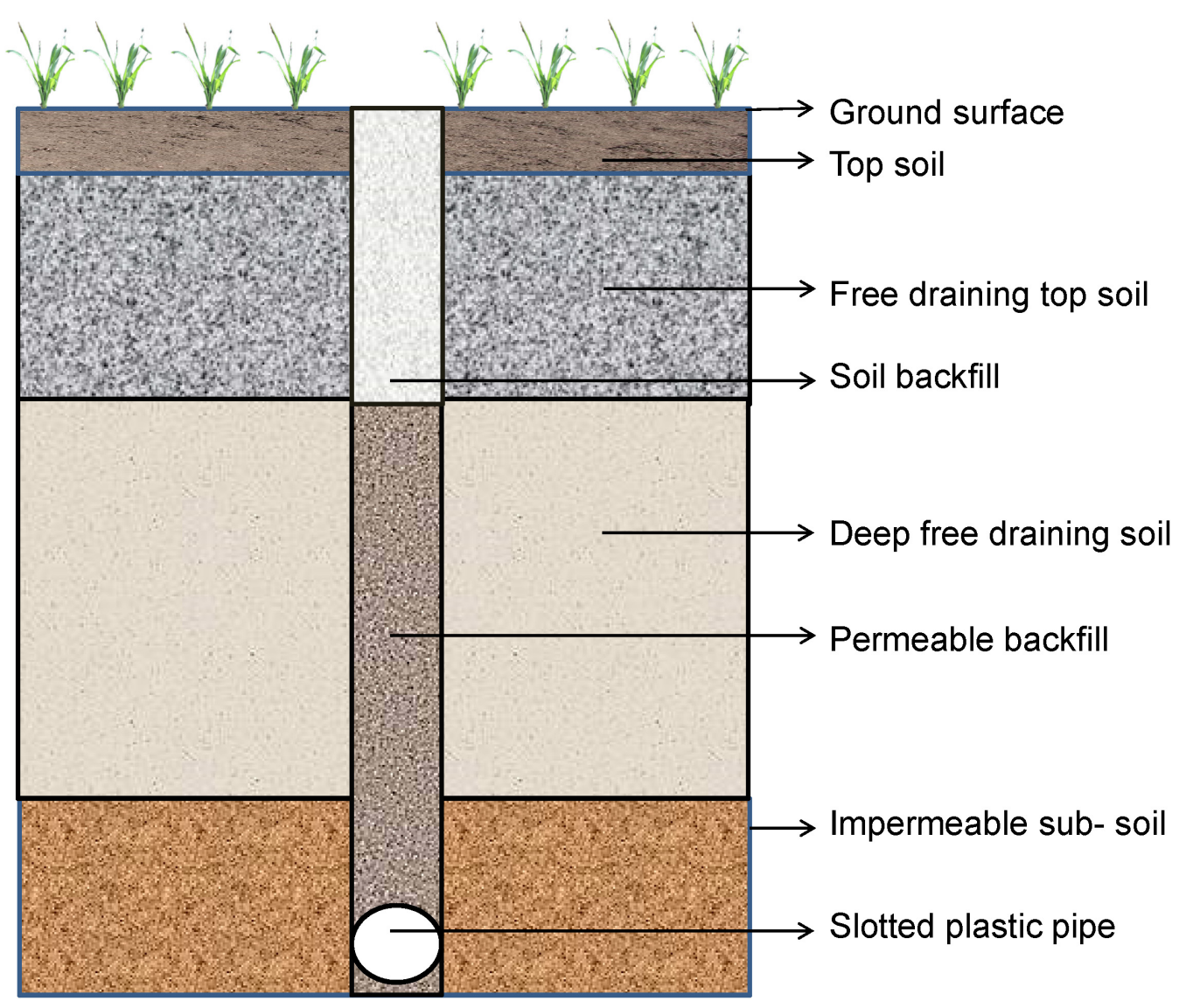

FIGURE $\mathbf{5}$ | Horizontal drainage system.

agricultural (ag) pipe drainage system throughout the season (Childs, 1943; Hallard and Armstrong, 1992; Tuohy et al., 2015, 2016). Mole drains are installed in close proximity to tile drains and are most suitable for low-permeability heavy soils such as clay (Monaghan et al., 2002; Monaghan and Smith, 2004). These drains should be installed at less than $600 \mathrm{~mm}$ from the ground surface and form 40-50 mm diameter circle of drainage (Gibson, 2014). A mole drain can be formed by dragging a metal object (viz. a blade like bullet with cylindrical foot, or mole plow) through the soil which creates an open channel. The installation cost of mole drainage is low but the moles should be re-formed at approximately 2- to 5-year intervals to uphold the channel integrity and optimize overall performance of the system (Tuohy et al., 2016, 2018). Combined drainage systems (mole and tile drainage) can be used efficiently to simulate water balance and drainage network system over a watershed, and to aid drainage management in a floodplain landscape (Tuohy et al., 2018).

\section{CROP MANAGEMENT}

There are a large and diverse number of crop management practices used by grain growers to alleviate the effects of waterlogging. These include: crop choice, waterlogging tolerant crop varieties, bio-drainage, and different agronomic practices such as sowing time, nutrient application and plant growth regulators (PGRs).

\section{Early Sowing and Vigorous Crops}

Crop management options to increase crop water use and decrease the incidence of waterlogging include early sowing and higher sowing rates (Gardner et al., 1992). Early sowing of wheat varieties showed better performance (Setter and Waters, 2003; Bassu et al., 2009; Ali et al., 2018) due to reduced risk of waterlogging damage through de-watering of the soil profile and avoiding waterlogging at vulnerable early growth stages (Gardner and Flood, 1993). Wheat, barley and rapeseed plants were less affected by early waterlogging (vegetative stages) than late (reproductive stages) (Ploschuk et al., 2018; Wollmer et al., 2018). Early sowing can also avoid late season terminal waterlogging events (Stapper and Harris, 1989). In addition, higher sowing rates can compensate for reduced tiller numbers and fertile heads (Watson et al., 1976; Belford et al., 1992).

Early crop vigor can be another important trait for waterlogging tolerance in the field (Sundgren et al., 2018). Tillering and reproductive stages are crucial for waterlogging tolerance in crops such as wheat and barley (Setter and Waters, 2003). Reduced nitrogen uptake is one of the main effects of 

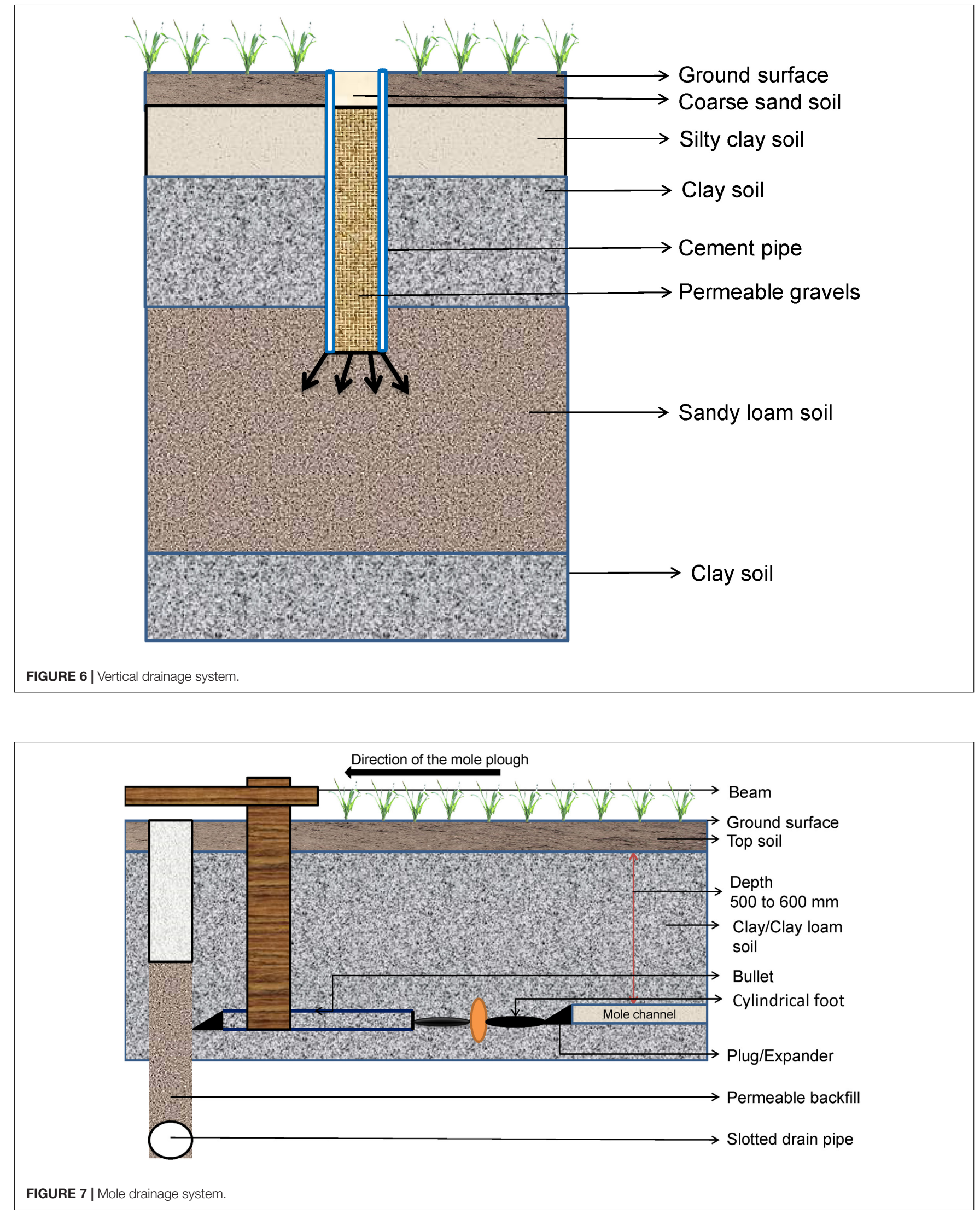
waterlogging stress in crops (Jaiswal and Srivastava, 2018; Nguyen L.T. et al., 2018). Early vigor may be linked with increased uptake of nitrogen (Liao et al., 2004; Sundgren et al., 2018). However, under normal conditions seedling growth rates can also vary with genotypic differences (Rebetzke et al., 2004). Further research may provide more insight into the interactions and possible use of early vigor to mitigate the effects of waterlogging.

\section{Bio-Drainage}

The incorporation of herbaceous perennial legumes such as lucerne, clovers and Messina (Melilotus siculus) adapted to waterlogging and inundation into cropping systems has been suggested to reduce waterlogging (Cocks, 2001; Nichols, 2018). Usually these deep rooted pasture plants can extract water and dry the soil to greater depths than most annual crops (McCaskill and Kearney, 2016). However, there is significant variation in tolerance to waterlogging between different pasture species (Cocks, 2001), and their suitability for grain production systems and how they would be integrated to provide maximum benefit has been identified as a gap in knowledge and warrants further investigation.

Bio-drainage or bio-pumping is the VD of soil water using specific types of fast growing tree vegetation with high evapotranspiration demand and is considered an economically viable option in dealing with the drainage congestion and environment hazards (Kapoor, 2000; Heuperman and Kapoor, 2003; Dash et al., 2005; Sarkar et al., 2018; Singh and Lal, 2018). Bio-drainage vegetation has been demonstrated to lower the rising water table around the root zone of adjacent cultivated crops in waterlogged areas through drainage (Roy Chowdhury et al., 2011; Sarkar et al., 2018; Singh and Lal, 2018).

Lowering of the rising water table is apparent within 5-10 years of growing vegetation and trees (Silberstein et al., 1999; Singh and Lal, 2018). If trees tolerant to waterlogging are introduced into the prone areas, these can easily assist in controlling water stagnation and rising water table (Banik et al., 2018; Sarkar et al., 2018). The right choice of plant species with optimum plant population and suitable plant geometry will help to control the elevated groundwater table in waterlogged areas and thus maintain the desired soil moisture regime for timely cultivation (Sarkar et al., 2018; Singh and Lal, 2018).

Prevention and remediation are the two stages of bio-drainage where the trees planted could provide a benefit to agriculture as well as resolving other issues such as waterlogging, salinity and shelter. Therefore, incorporation of a bio-drainage system with a conventional agriculture farming system could improve land and water productivity as well as the environment (Roy Chowdhury et al., 2011). Integration of bio-drainage with conventional drainage measures is an option to consider with the possibility of integration of silviculture and aquaculture with conventional agriculture to improve land and water productivity (Roy Chowdhury et al., 2011).

Bio-drainage systems may be established under both rainfed and irrigated conditions (Heuperman, 2000). When established under rainfed conditions, the plant roots reduce the soil bulk density and enhance groundwater recharge capacity. The roots also draw subsurface flow to reduce the water load. It is particularly useful when there is a perched water table and the water cannot easily move down the soil profile due to the presence of an impermeable layer. Recharge planting and slope break planting (Figure 8) may be adopted in the above situations. In irrigated and low lands, which are prone to waterlogging, the discharge planting method (Figures 8, 9) is useful (Donnan, 1947; Dash et al., 2005). In HRZs, application of vegetative buffer strips is also effective for controlling runoff quantity and quality (Borin et al., 2010; Kavian et al., 2018; Saleh et al., 2018). Vegetative buffer strips have also been proposed as one of the best management or conservation practices to protect water bodies from nutrients, antibiotics, bacteria and pesticides applied on adjacent agricultural fields (Muñoz-Carpena et al., 2010; Lin et al., 2011; Lerch et al., 2017; Muñoz-Carpena et al., 2018). Tree species with high transpiration rates are selected to mitigate waterlogging from canal seepage in irrigated areas. Water quality in supply canals is suitable and can be effectively intercepted and used by the trees planted along the canals (Dash et al., 2005; Singh and Lal, 2018). However, the efficiency of bio-drainage plantations needs to be verified in HRZs where permanent stagnant water is a real problem. Lack of proper knowledge, plantation techniques, expertise, motivation as well as maintenance are issues that need to be addressed to derive the real benefit of this system. In addition, the land under bio-drainage cannot be utilized for growing other crops, as in the case of conventional drainage (Dash et al., 2005; Sarkar et al., 2018; Singh and Lal, 2018). Therefore, an economic analysis of the bio-drainage endeavor is required on a case by case basis.

\section{Nutrient Application}

Nutrient deficiency is one of the major effects of waterlogging on plants, resulting in reduced photosynthesis and net carbon fixation ultimately leading to a reduction in growth and therefore yield (Bange et al., 2004). Application of essential nutrients will assist in mitigating the negative effects of abiotic stresses like waterlogging leading to increased productivity (Noreen et al., 2018). The use of enhanced-efficiency $\mathrm{N}$ fertilizers such as slow-release or controlled-release (SR/CR) fertilizers (Shaviv, 2001; Varadachari and Goertz, 2010) play an important role in improving plant growth and development under waterlogged conditions (Dinnes et al., 2002). Slow-release fertilizer can release nitrogen over a prolonged period during crop growth, thus maximize nitrogen-use efficiency (NUE) by synchronizing nitrogen release according to the crop demand (Lubkowski and Grzmil, 2007; Trenkel, 2010). Several studies (Ashraf et al., 2011; Habibzadeh et al., 2012; Najeeb et al., 2015) suggested that exogenously applied fertilizers could be effective if the nutrient ions enter into the root architecture, consequently, plants are able to recover from the injury caused by waterlogging. Application of fertilizer diminishes the effects of waterlogging of barley (Pang et al., 2007b), wheat (Kaur et al., 2017; Pereira et al., 2017; Zheng et al., 2017), maize (Rao et al., 2002), corn (Kaur et al., 2018), cotton (Guo et al., 2010; Wu et al., 2012; Li et al., 2013) and canola (Habibzadeh et al., 2012). In Australia, studies under both controlled-environments and field conditions have shown that additional CR urea application can mitigate waterlogging effects (Allen et al., 2010; Najeeb 


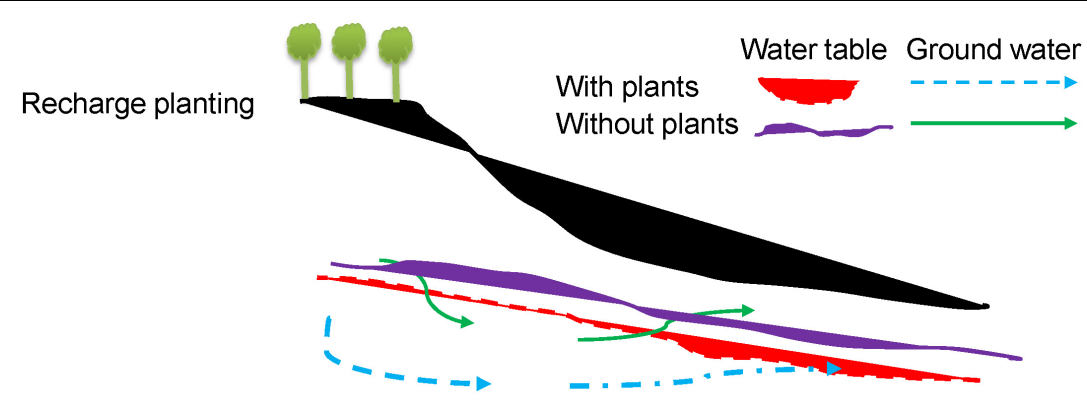

Slope break planting

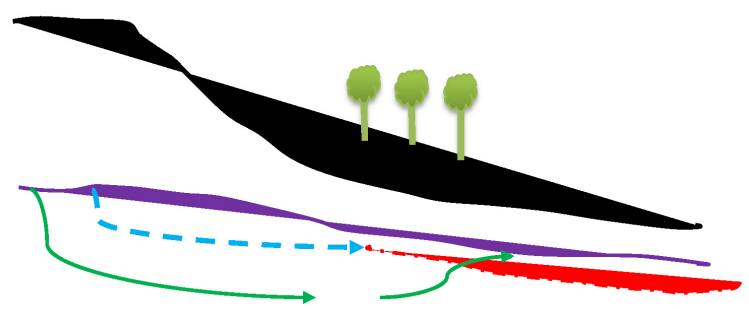

Discharge planting

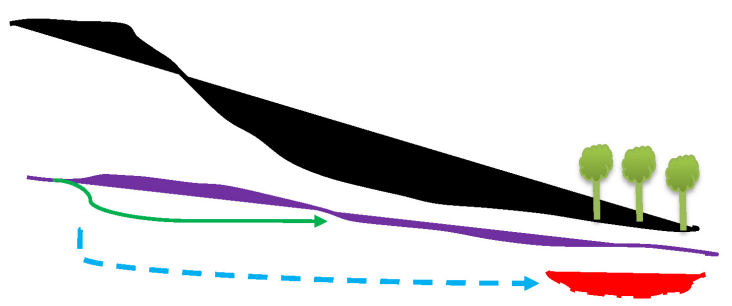

FIGURE 8 | Bio-drainage system.

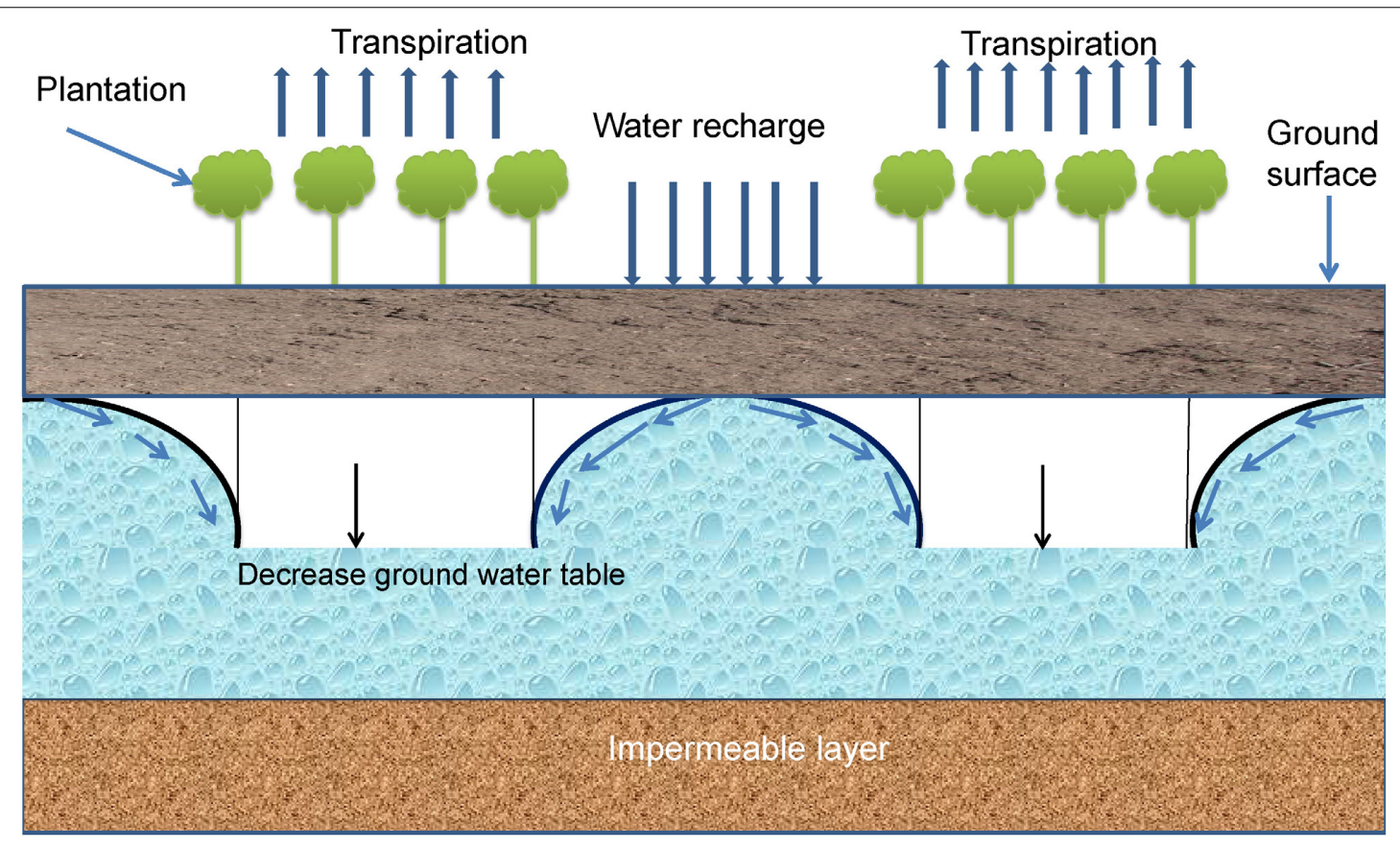

FIGURE 9 | Bio-drainage planting system (modified from Donnan, 1947). 
et al., 2015) of wheat and increase growth (Kisaakye et al., 2017) and grain yield by approximately 20\% (Robertson et al., 2009). Similar findings reported by Mondal et al. (2018) and Swarup and Sharma (1993) showed that increased rates of top-dressed urea significantly increased wheat grain yield on flooded sodic soils in India. Likewise, the use of polyolefincoated urea (a controlled-release fertilizer) resulted in a total $\mathrm{N}$ recovery of $66 \%$ in flood irrigated barley grown in north eastern Colorado, United States (Shoji et al., 2001). Fertilizer application also increases canopy duration and accelerates the production of photo-assimilates translocated to the grain compared with the straw thus increasing the harvest index (Kisaakye et al., 2015, 2017).

Potassium fertilizer has also been reported to ameliorate the detrimental effects of waterlogging in several crops including sugarcane (Sudama et al., 1998), rapeseed (Cong et al., 2009) and cotton (Ashraf et al., 2011). Exogenous application of various phosphorus (P) sources such as dairy cow manure (DCM) and meat and bone meal (MBM) is effective for producing optimum yields in P-deficient conditions during a wet growing season (Ylivainio et al., 2008, 2018). Application of farmyard manure also significantly increased grain $\mathrm{Fe}, \mathrm{Zn}, \mathrm{Cu}$ concentration of paddy under flooded conditions (Masunaga and Marques Fong, 2018). Similarly, foliar application of boron has been reported to increase overall plant growth and alleviate deleterious effect of waterlogging of maize (Sayed, 1998).

The use of fertilizers to alleviate waterlogging damage in broadacre cropping, even with high value crops, has been limited by lack of research and availability of information on their potential use in improving crop performance under waterlogged conditions (Lubkowski and Grzmil, 2007; Trenkel, 2010). Appropriate application methods, nutrient types, timing and rate should be considered to avoid the negative effect of tissue toxicities (e.g., manganese) (Silva et al., 2017; Huang et al., 2018) and nutrient imbalance on soil ecology (Rochester et al., 2001; Jackson and Ricard, 2003). The ability to predict waterlogging events (variable seasons) and therefore the crops' nitrogen demand also limits the effectiveness of SR/CR fertilizers and therefore raises the question of whether highly available $\mathrm{N}$ applications would be preferable when waterlogging limits growth (Lubkowski and Grzmil, 2007; Trenkel, 2010). Robertson et al. (2007) suggested that pre-waterlogging application of $\mathrm{N}$ fertilizer might not be effective on wheat at the tillering stage. Application of nitrogen fertilizer during or immediately following waterlogging was less effective than pre-waterlogging due to inefficient nutrient ion absorption capacity of impaired roots, high leaching risks in the wet soils and at the late growth phase additional fertilizer applied could cause excessive vegetative growth and harvesting problems of cotton plant (Najeeb et al., 2015). Therefore, this strategy has limitations on a large-scale as the damaging effects of waterlogging can only be partially alleviated by the addition of fertilizers because of the reduced capability of roots to absorb nutrients (Trought and Drew, 1980; Kisaakye et al., 2015, 2017). For example, a drop in root membrane potential by $60 \mathrm{mV}$, often observed under hypoxic conditions (Gill et al., 2018) will require a 10-fold increase in cation (e.g., $\mathrm{K}^{+}$or $\mathrm{NH}_{4}{ }^{+}$) concentration in the rhizosphere, to enable thermodynamically passive uptake (Gill et al., 2018). This approach is difficult to justify based on cost efficiency.

\section{Plant Growth Regulators}

Plant growth regulators may mitigate waterlogging damage of plants by applying at the appropriate growth stage (Nguyen H.C. et al., 2018; Ren et al., 2018; Wu H. et al., 2018). The application of PGRs such as auxins and cytokinins has been reported to improve plant growth under waterlogged conditions (Pang et al., 2007b; Ren et al., 2016). The two hormones act in concert to promote stomatal conductance and photosynthetic capacity of waterlogged plants (Drew et al., 1979). Synthetic auxin 1-naphthaleneacetic acid (1-NAA), was reported to promote the growth of adventitious roots in waterlogged barley plants (Pang et al., 2007b) and; exogenous application of a cytokinin, 6-benzyladenine (6-BA) can alleviate waterlogging injuries and increase yield of maize (Ren et al., 2016, 2018). Pre-waterlogging foliar application of ABA increased tolerance to successive waterlogging-induced injury in cotton plant by improving photosynthesis of leaf (Pandey et al., 2002; Kim et al., 2018). Triazoles are known as fungitoxic and also have plant-growth regulatory effects and protect plants against various stresses (Leul and Zhou, 1998; Rademacher, 2015). For example, paclobutrazol mitigates waterlogging induced damage in canola and sweet potato plants (Lin et al., 2006). Uniconazole can also increase the chlorophyll content and the activity of antioxidant enzymes in canola (Leul and Zhou, 1999). Under waterlogging condition, the application of tricyclazole [5-methyl-1,2,4-triazole(3,4-b) benzothiazole] also mitigates the damage in plants (Habibzadeh et al., 2013). However, due to inconsistent results there has been little commercial use of PGRs to alleviate waterlogging damage.

\section{Combined Application of Fertilizer and Growth Regulators}

Combined application of fertilizers and growth regulators can provide another option for ameliorating detrimental effects of waterlogging in crops, with the fertilizers acting as a nutrient supplier, while the PGRs assist with recovery from physiological injury (Li et al., 2013). 1\% urea $+0.5 \%$ potassium chloride and growth regulators [brassin $(0.02 \mathrm{mg} / \mathrm{L})+$ diethyl aminoethyl hexanoate $(10 \mathrm{mg} / \mathrm{L})]$ improved growth and yield of waterlogged cotton (Li et al., 2013). Both foliar nutrient and PGRs application provide opportunities for future research.

\section{Use of Anti-ethylene Agents}

Plant hypoxia-induced growth and yield losses could be the consequence of increased accumulation of ethylene (Shabala, 2011; Najeeb et al., 2018). Use of anti-ethylene agents such as 1-methylcyclopropene (1-MCP), amino ethoxyvinyl glycine (AVG), 1-aminocyclopropane-1-carboxylic acid (ACC), amino ethoxyacetic acid (AOA), silver and cobalt ions have been reported to inhibit the synthesis or accumulation of ethylene through blocking the biosynthetic pathway (Najeeb et al., 2017; Vwioko et al., 2017) of ethylene (McDaniel and Binder, 2012). 
TABLE 1 | Summary of advantages and disadvantages of different soil and crop management practices.

\begin{tabular}{|c|c|c|c|}
\hline $\begin{array}{l}\text { Soil and crop management } \\
\text { practices }\end{array}$ & $\begin{array}{l}\text { Advantages (in addition to reducing } \\
\text { waterlogging) }\end{array}$ & Disadvantages & Reference \\
\hline Surface drainage & $\begin{array}{l}\text { Both installation and maintenance are } \\
\text { simplest and cheapest }\end{array}$ & $\begin{array}{l}\text { Open drains with less cropping area; } \\
\text { needs periodic maintenance }\end{array}$ & $\begin{array}{l}\text { Food and Agriculture Organization } \\
\text { [FAO], 2002; Ritzema et al., 2008; } \\
\text { Ayars and Evans, 2015; Palla et al., } \\
2018\end{array}$ \\
\hline Raised bed system & Improvements in soil structure & $\begin{array}{l}\text { Efficiency depends on height of water } \\
\text { table; poorer weed control in furrows; } \\
\text { cost of modifying machinery; less } \\
\text { cropping area }\end{array}$ & $\begin{array}{l}\text { Bakker et al., 2005b, 2007; Roth et al., } \\
\text { 2005; Zhang, 2005; Acuña et al., 2011; } \\
\text { Gibson, } 2014\end{array}$ \\
\hline Pipe drains & $\begin{array}{l}\text { Well tested method for severe } \\
\text { waterlogging }\end{array}$ & $\begin{array}{l}\text { Needs outfall and periodic } \\
\text { maintenance; cost of installation is high }\end{array}$ & $\begin{array}{l}\text { Tanji, 1990; Food and Agriculture } \\
\text { Organization [FAO], 2002; Filipović } \\
\text { et al., 2014; Teixeira et al., } 2018\end{array}$ \\
\hline Vertical drainage & $\begin{array}{l}\text { Well tested method for severe } \\
\text { waterlogging }\end{array}$ & $\begin{array}{l}\text { Maintenance and operational costs are } \\
\text { higher than for horizontal pipe drainage } \\
\text { systems }\end{array}$ & $\begin{array}{l}\text { Christen et al., 2001; Food and } \\
\text { Agriculture Organization [FAO], 2002; } \\
\text { Kijne, 2006; Prathapar et al., } 2018\end{array}$ \\
\hline Mole drains & $\begin{array}{l}\text { Well tested method; cheaper than other } \\
\text { underground drainage }\end{array}$ & $\begin{array}{l}\text { Needs periodic maintenance; will not } \\
\text { maintain integrity in dispersive soils }\end{array}$ & $\begin{array}{l}\text { Tuohy et al., 2016, 2018; Dhakad et al., } \\
2018\end{array}$ \\
\hline Controlled traffic farming (CTF) & $\begin{array}{l}\text { Reduced soil compaction, erosion, } \\
\text { tillage costs, water and nutrient losses }\end{array}$ & $\begin{array}{l}\text { Variable results with different } \\
\text { conditions, such as different crops, soil } \\
\text { types and tillage }\end{array}$ & $\begin{array}{l}\text { Zhang, 2005; Chamen et al., 2006; } \\
\text { Guenette and Hernandez-Ramirez, } \\
\text { 2018; Thomsen et al., 2018; Bennett } \\
\text { et al., } 2019\end{array}$ \\
\hline $\begin{array}{l}\text { Strategic deep tillage and } \\
\text { subsoil manuring }\end{array}$ & $\begin{array}{l}\text { Decreases soil strength resulting in } \\
\text { deeper and denser rooting }\end{array}$ & $\begin{array}{l}\text { SDT with no added amendment is } \\
\text { often short-term nature, less effective in } \\
\text { hostile sub-soils, such as acidity, } \\
\text { sodicity or subsoil salinity }\end{array}$ & $\begin{array}{l}\text { Gajri et al., 1994; Bakker et al., 2007; } \\
\text { Roper et al., } 2015\end{array}$ \\
\hline Early sowing and vigorous crop & $\begin{array}{l}\text { Use of existing soil water provides a } \\
\text { buffer; avoids terminal waterlogging } \\
\text { events }\end{array}$ & Minor benefit with severe waterlogging & $\begin{array}{l}\text { Stapper and Harris, 1989; Setter and } \\
\text { Waters, 2003; Bassu et al., 2009; } \\
\text { Ploschuk et al., 2018; Sundgren et al., } \\
\text { 2018; Wollmer et al., } 2018\end{array}$ \\
\hline Bio-drainage & $\begin{array}{l}\text { Tried and tested at many locations with } \\
\text { success }\end{array}$ & $\begin{array}{l}\text { Needs proper plantation techniques, } \\
\text { expertise, thinning, pruning, and } \\
\text { harvesting }\end{array}$ & $\begin{array}{l}\text { Kapoor, 2000; Food and Agriculture } \\
\text { Organization [FAO], 2002; Heuperman } \\
\text { and Kapoor, 2003; Dash et al., 2005; } \\
\text { Lin et al., 2011; Lerch et al., 2017; } \\
\text { Muñoz-Carpena et al., 2018; Sarkar } \\
\text { et al., 2018; Singh and Lal, 2018; }\end{array}$ \\
\hline $\begin{array}{l}\text { Nutrient application, in } \\
\text { particular, } \mathrm{N}\end{array}$ & $\begin{array}{l}\text { Improving plant growth and } \\
\text { development }\end{array}$ & $\begin{array}{l}\text { Appropriate methods, nutrient types, } \\
\text { timing and rate should be considered } \\
\text { for large-scale application }\end{array}$ & $\begin{array}{l}\text { Rao et al., 2002; Pang et al., 2007b; } \\
\text { Guo et al., 2010; Ashraf et al., 2011; } \\
\text { Habibzadeh et al., 2012; Wu et al., } \\
\text { 2012; Li et al., 2013; Najeeb et al., } \\
\text { 2015; Kaur et al., 2017, 2018; Pereira } \\
\text { et al., 2017; Zheng et al., } 2017\end{array}$ \\
\hline Plant growth regulators & $\begin{array}{l}\text { Promote stomatal conductance and } \\
\text { photosynthetic capacity of waterlogged } \\
\text { plants }\end{array}$ & $\begin{array}{l}\text { Appropriate methods, timing and rate } \\
\text { should be considered for large-scale } \\
\text { application; unproven in broad scale } \\
\text { agriculture }\end{array}$ & $\begin{array}{l}\text { Drew et al., 1979; Lin et al., 2006; } \\
\text { Habibzadeh et al., 2013; Ren et al., } \\
\text { 2016, } 2018\end{array}$ \\
\hline Use of anti-ethylene agents & $\begin{array}{l}\text { Increase both photosynthesis and fruit } \\
\text { retention; diminish crop loss induced by } \\
\text { ethylene accumulation }\end{array}$ & Untested in broad scale agriculture & $\begin{array}{l}\text { Kawakami et al., 2010; Shabala, 2011; } \\
\text { Najeeb et al., } 2018\end{array}$ \\
\hline $\begin{array}{l}\text { Pretreatment with hydrogen } \\
\text { peroxide }\end{array}$ & $\begin{array}{l}\text { Protect crops from oxidative damage } \\
\text { caused by waterlogging }\end{array}$ & Untested in broad scale agriculture & $\begin{array}{l}\text { Gechev et al., 2002; Ishibashi et al., } \\
\text { 2011; Rajaeian and Ehsanpour, 2015; } \\
\text { Savvides et al., 2016; Andrade et al., } \\
2018\end{array}$ \\
\hline Tolerant species and varieties & Cost effective for farmers & $\begin{array}{l}\text { The introduction of waterlogging } \\
\text { tolerance into existing plant varieties is } \\
\text { time consuming and complex }\end{array}$ & $\begin{array}{l}\text { Davies and Hillman, 1988; Gardner and } \\
\text { Flood, 1993; Zhou et al., 2007; Gill } \\
\text { et al., 2018; Huang et al., } 2018\end{array}$ \\
\hline
\end{tabular}

Application of 1-MCP and AVG has been shown to diminish crop loss induced by ethylene accumulation (Kawakami et al., 2010; Najeeb et al., 2018). Brito et al. (2013) reported a positive effect of 1-MCP and AVG on cotton seed and lint yield.
They determined that the initial reproductive phase is the best time for AVG application for improving cotton yield under waterlogging condition. In cotton, waterlogging prompts ethylene accumulation leading to young fruit abscission (Najeeb 


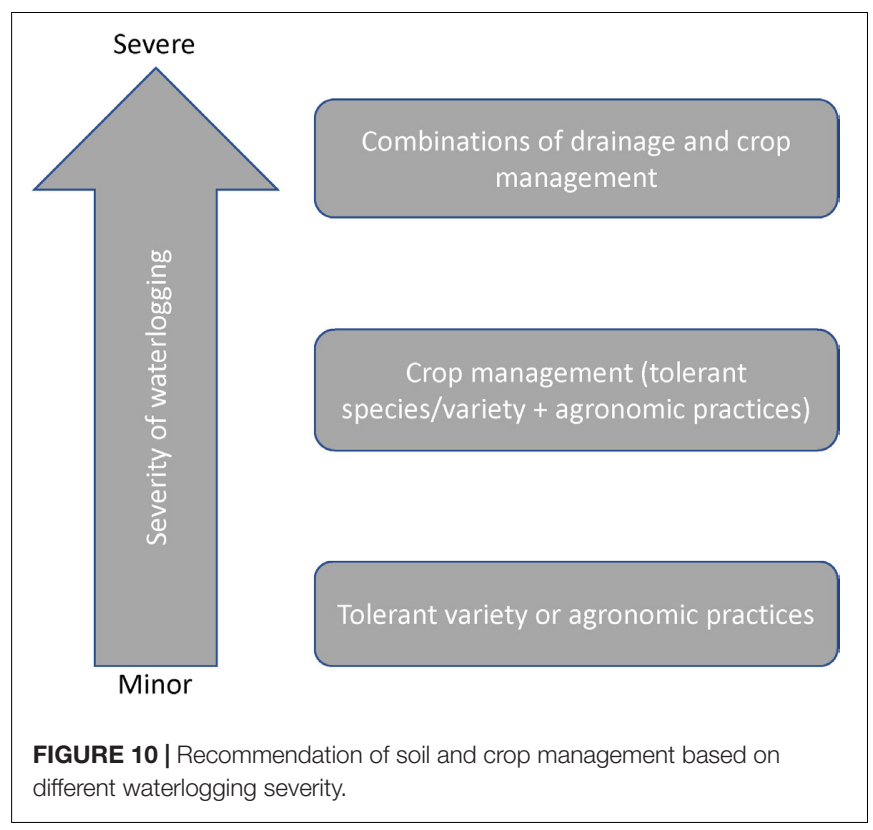

et al., 2017, 2018). During waterlogging conditions, an inverse link between ethylene production and cotton yield has also been found, therefore the application of AVG can regulate ethylene production and increase both photosynthesis and fruit retention of cotton (Bange et al., 2010; Najeeb et al., 2017). Likewise, the positive effect of 1-MCP has been studied on hypoxia cotton plants, where it also blocked ethylene action and enhanced physiological processes, such as antioxidant enzyme activity and stomatal resistance (Kawakami et al., 2010). Utilizing an ethylene-insensitive cotton mutant (eliminating ethylene sensitivity) may be another option for waterlogged areas, where the mutant plant showed a remarkably improved yield of cotton (Najeeb et al., 2017). There is further research required to fully understand the ethylene mediated pathways in other crops such as grains.

\section{Pretreatment With Hydrogen Peroxide}

Pretreatment of crops with an agent may be an effective way to increase tolerance to different stresses (Jisha et al., 2013). For example, pretreatment with $\mathrm{H}_{2} \mathrm{O}_{2}$ can protect crops from oxidative damage caused by waterlogging, high light intensity, low temperature, salt stress, drought and exposure to heavy metals (Gechev et al., 2002; Ishibashi et al., 2011; Rajaeian and Ehsanpour, 2015; Savvides et al., 2016; Andrade et al., 2018). Priming seeds with $\mathrm{H}_{2} \mathrm{O}_{2}$ generated seedlings exhibiting elevated activity of antioxidant enzymes, low $\mathrm{H}_{2} \mathrm{O}_{2}$ and $\mathrm{O}_{2}{ }^{-}$. content, and low cell membrane damage under waterlogged conditions (Andrade et al., 2018). $\mathrm{H}_{2} \mathrm{O}_{2}$ pre-treatment also resulted in increases in net photosynthetic rate and photosynthetic pigments, root volume, high biomass accumulation, and stem diameter (Andrade et al., 2018). Despite much research being conducted on priming with agents against biotic and abiotic stresses (Mustafa et al., 2017; Ashraf et al., 2018; Lal et al.,
2018), pre-treatment with $\mathrm{H}_{2} \mathrm{O}_{2}$ tolerant to waterlogging still in its infancy.

\section{Use of Tolerant Species and Varieties}

One of the key economical approaches for reducing the loss caused by waterlogging is to introduce waterlogging tolerance into existing plant varieties (Zhou, 2010; Tewari and Mishra, 2018; Wani et al., 2018). Genetic differences exist for tolerance to waterlogging in different crops (Setter and Waters, 2003) which include barley (Takeda and Fukuyama, 1986; Qiu, 1991; Pang et al., 2004; Xiao et al., 2007; Zhou et al., 2007; Huang et al., 2015; Zhang et al., 2015; Romina et al., 2018) and wheat (Davies and Hillman, 1988; Gardner and Flood, 1993; Huang et al., 1994; Herzog et al., 2016; Nguyen T.N. et al., 2018; Wu $\mathrm{X}$. et al., 2018). However, waterlogging tolerance is a complex trait which is controlled by many different mechanisms, such as aerenchyma formation in roots (Zhang et al., 2015; Luan et al., 2018; Pujol and Wissuwa, 2018) under waterlogging stress, tolerance to secondary metabolites (Pang et al., 2006), ion toxicities (Huang et al., 2018), the maintenance of membrane potential (Gill et al., 2018) and control of ROS production under stress, with many QTL being reported to control these traits (Li et al., 2008; Zhou, 2011; Zhang et al., 2017; Huang et al., 2018; Gill et al., 2018). The success of a breeding program relies on the discovery of genes and linked markers to various tolerance mechanisms, which enable breeders to pyramid tolerance genes.

\section{SUMMARY AND RECOMMENDATIONS}

Many soil and crop management practices have been employed to alleviate waterlogging in crop production systems as summarized in Table 1. For severe waterlogging, combinations of drainage and crop management will be the foremost step (Figure 10). For minor waterlogging, choosing tolerant varieties or applying appropriate agronomic practices can be effective.

There are still significant knowledge gaps in our understanding of the advantages or disadvantages of relevant management measures under different soil types or different crops, management of other macro- and micronutrients; and the genetic basis of plants' adaptation to hypoxia and elemental toxicities in waterlogged soils. While many tolerance mechanisms and related quantitative trait loci (QTL) have been reported, most of them are focused around oxygen availability and largely ignore other constraints imposed by waterlogged soils.

For improved mitigation strategies, further research should be focused on the following aspects:

- Comparison of the cost/benefit analyses of different drainage strategies;

- Understanding the mechanisms of nutrient loss during waterlogging and quantifying the benefits of nutrient application;

- Increasing soil profile de-watering through soil improvement and agronomic strategies; 
- Increased specificity of the interaction between different management practices and environment (soil types, severity of waterlogging, etc.) as well as among management practices.

- Discovering new (non-oxygen-associated) QTLs; the effectiveness of these mechanisms/QTL (and combined) on improving waterlogging tolerance in paddocks with soils with multiple constraints; the effect of these QTL on other agronomic, yield and quality traits, as well as management packages for varieties with diverse waterlogging tolerance genes.

\section{REFERENCES}

Acuña, T. B., Dean, G., and Riffkin, P. (2011). Constraints to achieving high potential yield of wheat in a temperate, high-rainfall environment in southeastern Australia. Crop Pasture Sci. 62, 125-136. doi: 10.1071/CP10271

Aldana, F., García, P. N., and Fischer, G. (2014). Effect of waterlogging stress on the growth, development and symptomatology of cape gooseberry (Physalis peruviana L.) plants. Rev. Acad. Colomb. Cienc. Exactas Fís. Nat. 38, 393-400. doi: $10.18257 /$ raccefyn. 114

Ali, N., Dayal, A., Thomas, N., Lal, G., and Gupta, J. (2018). Effect of different sowing time on seed vigour parameters of wheat (Triticum aestivum L.) varieties. Int. J. Pure Appl. Biosci. 6, 1532-1538. doi: 10.18782/2320-7051.6627

Allen, D. E., Kingston, G., Rennenberg, H., Dalal, R. C., and Schmidt, S. (2010). Effect of nitrogen fertilizer management and waterlogging on nitrous oxide emission from subtropical sugarcane soils. Agric. Ecosyst. Environ. 136, 209-217. doi: 10.1016/j.agee.2009.11.002

Alwang, J., Sabry, S., Shideed, K., Swelam, A., and Halila, H. (2018). Economic and food security benefits associated with raised-bed wheat production in Egypt. Food Sec. 10, 589-601. doi: 10.1007/s12571-018-0794-3

Amare, T., Terefe, A., Selassie, Y. G., Yitaferu, B., Wolfgramm, B., and Hurni, H. (2013). Soil properties and crop yields along the terraces and toposequece of Anjeni Watershed, Central Highlands of Ethiopia. J. Agric. Sci. 5:134.

Andrade, C. A., de Souza, K. R. D., de Oliveira Santos, M., da Silva, D. M., and Alves, J. D. (2018). Hydrogen peroxide promotes the tolerance of soybeans to waterlogging. Sci. Hortic. 232, 40-45. doi: 10.1016/j.scienta.2017.12.048

Arbona, V., López-Climent, M. F., Pérez-Clemente, R. M., and Gómez-Cadenas, A. (2009). Maintenance of a high photosynthetic performance is linked to flooding tolerance in citrus. Environ. Exp. Bot. 66, 135-142. doi: 10.1016/j.envexpbot. 2008.12.011

Armstrong, R., Eagle, C., and Flood, R. (2015). Improving grain yields on a sodic clay soil in a temperate, medium-rainfall cropping environment. Crop Pasture Sci. 66, 492-505. doi: 10.1071/CP14210

Armstrong, R., Sale, P., Tavakkoli, E., Wilhelm, N., Davenport, D., Dean, G., et al. (2017). "Can subsoil amelioration improve the productivity of grain production in medium-high rainfall environments?", in Proceedings of the 18th Australian Agronomy Conference 2017, (Ballarat: Australian Society of Agronomy Inc), $24-28$.

Armstrong, W. (1980). Aeration in Higher Plants Advances in Botanical Research. New York, NY: Elsevier, 225-332.

Armstrong, W., Justin, S., Beckett, P., and Lythe, S. (1991). Root adaptation to soil waterlogging. Aquat. Bot. 39, 57-73. doi: 10.1016/0304-3770(91)90022-W

Ashraf, M., and Arfan, M. (2005). Gas exchange characteristics and water relations in two cultivars of Hibiscus esculentus under waterlogging. Biol. Plant. 49, 459-462. doi: 10.1007/s10535-005-0029-2

Ashraf, M. A., Ahmad, M. S. A., Ashraf, M., Al-Qurainy, F., and Ashraf, M. Y. (2011). Alleviation of waterlogging stress in upland cotton (Gossypium hirsutum L.) by exogenous application of potassium in soil and as a foliar spray. Crop Pasture Sci. 62, 25-38. doi: 10.1071/CP09225

Ashraf, M. A., Akbar, A., Askari, S. H., Iqbal, M., Rasheed, R., and Hussain, I. (2018). "Recent advances in abiotic stress tolerance of plants through chemical priming: An overview," in Advances in Seed Priming, eds A. Rakshit and H. Bahadur Singh (Singapore: Springer), 51-79. doi: 10.1007/978-981-130032-5_4

\section{AUTHOR CONTRIBUTIONS}

SM and GP prepared the draft. GD supervised the project. GP, $\mathrm{GD}, \mathrm{BF}, \mathrm{SS}$, and $\mathrm{MZ}$ reviewed and revised the manuscript.

\section{FUNDING}

This project was supported by the Grains Research and Development Corporation (GRDC) grant to GD, MZ, $\mathrm{GP}$, and BF.

Ayars, J. E., and Evans, R. G. (2015). Subsurface drainage-What's next? Irrigation Drainage 64, 378-392. doi: 10.1002/ird.1893

Azhar, A., Makihara, D., Naito, H., and Ehara, H. (2018). Evaluating sago palm (Metroxylon sagu Rottb.) photosynthetic performance in waterlogged conditions: utilizing pulse-amplitude-modulated (PAM) fluorometry as a waterlogging stress indicator. J. Saudi Soc. Agric. Sci. (in press). doi: 10.1016/ j.jssas.2018.05.004

Bai, T., Li, C., Li, C., Liang, D., and Ma, F. (2013). Contrasting hypoxia tolerance and adaptation in Malus species is linked to differences in stomatal behavior and photosynthesis. Physiol. Plant. 147, 514-523. doi: 10.1111/j.1399-3054.2012. 01683.x

Bailey-Serres, J., and Voesenek, L. (2008). Flooding stress: acclimations and genetic diversity. Annu. Rev. Plant Biol. 59, 313-339. doi: 10.1146/annurev.arplant.59. 032607.092752

Bakker, D., Hamilton, G., Houlbrooke, D., and Spann, C. (2005a). The effect of raised beds on soil structure, waterlogging, and productivity on duplex soils in Western Australia. Soil Res. 43, 575-585. doi: 10.1071/SR03118

Bakker, D., Houlbrooke, D., Hamilton, G., and Spann, C. (2005b). A Manual for Raised Bed Farming in Western Australia. Perth: Department of Agriculture and Food.

Bakker, D., Hamilton, G., Houlbrooke, D., Spann, C., and Van Burgel, A. (2007). Productivity of crops grown on raised beds on duplex soils prone to waterlogging in Western Australia. Aust. J. Exp. Agric. 47, 1368-1376. doi: 10.1071/EA06273

Bange, M., Milroy, S., Ellis, M., and Thongbai, P. (2010). “Opportunities to reduce the impact of water-logging on cotton," in Proceedings of the 15 Agronomy Conference, Lincoln.

Bange, M., Milroy, S., and Thongbai, P. (2004). Growth and yield of cotton in response to waterlogging. Field Crops Res. 88, 129-142. doi: 10.1093/pcp/ pcp 163

Banik, M., Sarkar, A., Ghatak, P., Ray, R., and Patra, S. (2018). Reclamation of waterlogged lowland in indo-gangetic alluvial plains using some biodrainage species. Int. J. Curr. Microbiol. Appl. Sci. 7, 1028-1038. doi: 10.20546/ijcmas. 2018.702.127

Barrett-Lennard, E. (2003). The interaction between waterlogging and salinity in higher plants: causes, consequences and implications. Plant Soil 253, 35-54. doi: 10.1023/A:1024574622669

Bassu, S., Asseng, S., Motzo, R., and Giunta, F. (2009). Optimising sowing date of durum wheat in a variable mediterranean environment. Field Crops Res. 111, 109-118. doi: 10.1016/j.fcr.2008.11.002

Bastick, C., and Walker, M. (2000). Extent and Impacts of Dryland Salinity in Tasmania. Canberra: National Land and Water Resources Audit Dryland Salinity Project Report.

Belford, R., Dracup, M., and Tennant, D. (1992). Limitations to growth and yield of cereal and lupin crops on duplex soils. Aust. J. Exp. Agric. 32, 929-945. doi: 10.1071/EA9920929

Belmonte, S. A., Luisella, C., Stahel, R. J., Bonifacio, E., Novello, V., Zanini, E., et al. (2018). Effect of long-term soil management on the mutual interaction among soil organic matter, microbial activity and aggregate stability in a vineyard. Pedosphere 28, 288-298. doi: 10.1016/S1002-0160(18)60015-3

Bennett, J. M., Roberton, S. D., Marchuk, S., Woodhouse, N. P., Antille, D. L., Jensen, T. A., et al. (2019). The soil structural cost of traffic from heavy machinery in Vertisols. Soil Till. Res. 185, 85-93. doi: 10.1016/j.still.2018.09.007 
Blann, K. L., Anderson, J. L., Sands, G. R., and Vondracek, B. (2009). Effects of agricultural drainage on aquatic ecosystems: a review. Crit. Rev. Environ. Sci. Technol. 39, 909-1001. doi: 10.1080/10643380801977966

Blokhina, O., Virolainen, E., and Fagerstedt, K. V. (2003). Antioxidants, oxidative damage and oxygen deprivation stress: a review. Ann. Bot. 91, 179-194. doi: $10.1093 / \mathrm{aob} / \mathrm{mcf1} 18$

Bochtis, D., and Vougioukas, S. (2008). Minimising the non-working distance travelled by machines operating in a headland field pattern. Biosyst. Eng. 101, 1-12. doi: 10.1016/j.biosystemseng.2008.06.008

Bogunovic, I., Bilandzija, D., Andabaka, Z., Stupic, D., Comino, J. R., Cacic, M., et al. (2017). Soil compaction under different management practices in a Croatian vineyard. Arab. J. Geosci. 10:340. doi: 10.1007/s12517-017-3105-y

Borin, M., Passoni, M., Thiene, M., and Tempesta, T. (2010). Multiple functions of buffer strips in farming areas. Eur. J. Agron. 32, 103-111. doi: 10.1007/s00267011-9696-2

Boru, G., Vantoai, T., Alves, J., Hua, D., and Knee, M. (2003). Responses of soybean to oxygen deficiency and elevated root-zone carbon dioxide concentration. Ann. Bot. 91, 447-453. doi: 10.1093/aob/mcg040

Bos, M. G. and Boers, T. M. (1994). "Land drainage: why and how?" In Drainage Principles and Applications, ed. H.P. Ritzema (Wageningen: International Institute for Land Reclamation \& Improvement), 23-32.

Brady, N., and Weil, R. (2008). Soil Colloids: Seat of Soil Chemical And Physical Acidity. Upper Saddle River, NJ: Pearson Education Inc.

Brito, G. G. D., Ferreira, A. C. D. B., Borin, A. L. D. C., and Morello, C. D. L. (2013). 1-Methylcyclopropene and Aminoethoxyvinylglycine effects on yield components of field-grown cotton. Ciênc. Agrotecnol. 37, 9-16. doi: 10.1590/ S1413-70542013000100001

Bullock, A., and Acreman, M. (2003). The role of wetlands in the hydrological cycle. Hydrol. Earth Syst. Sci. Discuss. 7, 358-389. doi: 10.5194/hess-7-358-2003

Cannarozzi, G., Weichert, A., Schnell, M., Ruiz, C., Bossard, S., Blösch, R., et al. (2018). Waterlogging affects plant morphology and the expression of key genes in tef (Eragrostis tef). Plant Direct 2:e00056. doi: 10.1002/pld3.56

Cannell, R., and Jackson, M. B. (1981). Alleviating Aeration Stresses [Soil, Plant Growth and Crop Production]. Modifying the Root Environment to Reduce Crop Stress, eds G. F. Arkin and H. M. Taylor (St. Joseph, MI: American Society of Agricultural Engineers).

Cannell, R. Q., Belford, R. K., Gales, K., Dennis, C. W., and Prew, R. D. (1980). Effects of waterlogging at different stages of development on the growth and yield of winter wheat. J. Sci. Food Agric. 31, 117-132. doi: 10.1002/jsfa. 2740310203

Castanheira, P. J., and Serralheiro, R. P. (2010). Impact of mole drains on salinity of a vertisoil under irrigation. Biosyst. Eng. 105, 25-33. doi: 10.1016/j. biosystemseng.2009.08.010

Celestina, C., Midwood, J., Sherriff, S., Trengove, S., Hunt, J., Tang, C., et al. (2018). Crop yield responses to surface and subsoil applications of poultry litter and inorganic fertiliser in south-eastern Australia. Crop Pasture Sci. 69, 303-316. doi: 10.1071/CP17439

Chamen, T. (2015). Controlled traffic farming-from worldwide research to adoption in Europe and its future prospects. Acta Technol. Agric. 18, 64-73. doi: 10.1515/ata-2015-0014

Chamen, T., Cottage, C. C., and Maulden, B. (2006). 'Controlled Traffic' Farming: Literature Review and Appraisal of Potential Use in the UK, HGCA Research Review No. 59. Maulden: The Home-Grown Cereals Authority.

Chamizo, S., Cantón, Y., Rodríguez-Caballero, E., and Domingo, F. (2016). Biocrusts positively affect the soil water balance in semiarid ecosystems. Ecohydrology 9, 1208-1221. doi: 10.1002/eco.1719

Chandio, A. S., Lee, T. S., and Mirjat, M. S. (2013). Simulation of horizontal and vertical drainage systems to combat waterlogging problems along the Rohri Canal in Khairpur District, Pakistan. J. Irrigation Drainage Eng. 139, 710-717. doi: 10.1061/(ASCE)IR.1943-4774.0000590

Chen, H., Wu, W., Liu, X., and Li, H. (2010). Effect of wheel traffic on working resistance of agricultural machinery in field operation. Trans. Chin. Soc. Agric. Machinery 41, 52-98.

Childs, E. (1943). Studies in mole-draining Interim report on an experimental drainage field. J. Agric. Sci. 33, 136-146. doi: 10.1017/S002185960000650X

Christen, E., and Skehan, D. (2001). Design and management of subsurface horizontal drainage to reduce salt loads. J. Irrigation Drainage Eng. 127, 148-155. doi: 10.1061/(ASCE)0733-9437(2001)127:3(148)
Christen, E. W., Ayars, J. E., and Hornbuckle, J. W. (2001). Subsurface drainage design and management in irrigated areas of Australia. Irrigation Sci. 21, 35-43.

Christianson, J. A., Llewellyn, D. J., Dennis, E. S., and Wilson, I. W. (2010). Comparisons of early transcriptome responses to low-oxygen environments in three dicotyledonous plant species. Plant Signal. Behav. 5, 1006-1009. doi: $10.1093 / \mathrm{pcp} / \mathrm{pcp} 163$

Christy, B., Clough, A., Riffkin, P., Norton, R., Midwood, J., and O'Leary, G. (2015). Managing Crop Inputs in a High Yield Potential Environment-Hrz of Southern Australia. Melbourne: Department of Economic Development, Jobs, Transport \& Resources (DEDJTR).

Chu, X., Han, G., Xing, Q., Xia, J., Sun, B., Yu, J., et al. (2018). Dual effect of precipitation redistribution on net ecosystem CO2 exchange of a coastal wetland in the Yellow River Delta. Agric. For. Meteorol. 249, 286-296. doi: 10.1016/j.agrformet.2017.11.002

Cocks, P. (2001). Ecology of herbaceous perennial legumes: a review of characteristics that may provide management options for the control of salinity and waterlogging in dryland cropping systems. Aust. J. Agricu. Res. 52, 137-151. doi: 10.1071/AR99170

Collaku, A., and Harrison, S. (2005). Heritability of waterlogging tolerance in wheat. Crop Sci. 45, 722-727. doi: 10.2135/cropsci2005. 0722

Collis, C. (2015). Raised Beds Exemplify on-Farm Adaptation. GRDC GroundCover $^{T M}$. Available at: https://grdc.com.au/resources-andpublications/groundcover/ground-cover-issue-117-july-august-2015/raisedbeds-exemplify-on-farm-adaptation

Colmer, T. D., and Greenway, H. (2011). Ion transport in seminal and adventitious roots of cereals during O2 deficiency. J. Exp. Bot. 62, 39-57. doi: 10.1093/jxb/ erq271

Cong, Y., Li, Y. J., Zhou, C. J., Zou, C. S., Zhang, X. K., Liao, X., et al. (2009). Effect of application of nitrogen, phosphorus and potassium fertilizers on yield in rapeseed (Brassica napus L.) under the waterlogging stress. Plant Nutr. Fertilizer Sci. $15,1122-1129$.

Coutinho, I. D., Henning, L. M. M., Döpp, S. A., Nepomuceno, A., Moraes, L. A. C., Marcolino-Gomes, J., et al. (2018). Flooded soybean metabolomic analysis reveals important primary and secondary metabolites involved in the hypoxia stress response and tolerance. Environ. Exp. Bot. 153, 176-187. doi: 10.1016/j.envexpbot.2018.05.018

Cox, J., and McFarlane, D. (1995). The causes of waterlogging in shallow soils and their drainage in southwestern Australia. J. Hydrol. 167, 175-194. doi: 10.1016/0022-1694(94)02614-H

Cox, J., McFarlane, D., and Skaggs, R. (1994). Field-evaluation of DRAINMOD for predicting waterlogging intensity and drain performance in south-western Australia. Soil Res. 32, 653-671. doi: 10.1071/ SR9940653

Cox, S. A., Sutton, R. P., Stoltz, R. P., and Knobloch, T. S. (2005). "Determination of effective drainage area for tight gas wells," in Paper Presented at the SPE Eastern Regional Meeting, (Houston,TX: Society of Petroleum Engineers). doi: 10.2118/98035-MS

Crabtree, W. L. (1989). Cereal grain yield responses to deep ripping on duplex soils. Aust. J. Exp. Agric. 29, 691-694. doi: 10.1071/EA9890691

Crawford, R. (1982). "Physiological responses to flooding," in Physiological Plant Ecology II, eds O. L. Lange, P. S. Nobel, C. B. Osmond, and H. Ziegler (Berlin: Springer), 453-477.

da Ponte, N. H. T., Nunes Santos, R. I., Lima Lopes, Filho, W. R., Lisboa Cunha, R., Murad Magalhães, M., et al. (2019). Morphological assessments evidence that higher number of pneumatophores improves tolerance to longterm waterlogging in oil palm (Elaeis guineensis) seedlings. Flora 250, 52-58. doi: 10.1016/j.flora.2018.11.017

Dash, C., Sarangi, A., Singh, A., and Dahiya, S. (2005). Bio-drainage: an alternate drainage technique to control waterlogging and salinity. J. Soil Water Conserv. India 4, 149-155.

Davies, M., and Hillman, G. (1988). Effects of soil flooding on growth and grain yield of populations of tetraploid and hexaploid species of wheat. Ann. Bot. 62, 597-604. doi: 10.1093/oxfordjournals.aob. a087699

Davies, S., Blackwell, P., Bakker, D., Scanlon, C., Roper, M., and Ward, P. (2012). "Developing and assessing agronomic strategies for water repellent soils," in Crop Updates, (Perth: GRDC/DAFWA), 71-77. 
de San Celedonio, R. P., Abeledo, L. G., Brihet, J., and Miralles, D. J. (2016). Waterlogging affects leaf and tillering dynamics in wheat and barley. J. Agron. Crop Sci. 202, 409-420. doi: 10.1111/jac.12151

Dhakad, S., Ambawatia, G., Verma, G., Patel, S., Rao, K. R., and Verma, S. (2018). Performance of Mole drain system for soybean (glycine max)-wheat (Triticum aestivum) cropping system of madhya pradesh. Int. J. Curr. Microbiol. Appl. Sci. 7, 2107-2112. doi: 10.20546/ijcmas.2018.702.251

Dinnes, D. L., Karlen, D. L., Jaynes, D. B., Kaspar, T. C., Hatfield, J. L., Colvin, T. S., et al. (2002). Nitrogen management strategies to reduce nitrate leaching in tile-drained Midwestern soils. Agron. J. 94, 153-171. doi: 10.2134/agronj2002. 1530

Donnan, W. W. (1947). Model tests of a tile-spacing formula 1. Soil Sci. Soc. Am. J. 11, 131-136. doi: 10.2136/sssaj1947.036159950011000C0025x

Dore, M. H. (2005). Climate change and changes in global precipitation patterns: what do we know? Environ. Int. 31, 1167-1181. doi: 10.1016/j.envint.2005. 03.004

Drew, M., and Lynch, J. M. (1980). Soil anaerobiosis, microorganisms, and root function. Ann. Rev. Phytopathol. 18, 37-66. doi: 10.1146/annurev.py.18.090180. 000345

Drew, M., and Sisworo, E. (1977). Early effects of flooding on nitrogen deficiency and leaf chlorosis in barley. New Phytol. 79, 567-571. doi: 10.1111/j.1469-8137. 1977.tb02241.x

Drew, M., Sisworo, E., and Saker, L. (1979). Alleviation of waterlogging damage to young barley plants by application of nitrate and a synthetic cytokinin, and comparison between the effects of waterlogging, nitrogen deficiency and root excision. New Phytol. 82, 315-329. doi: 10.1111/j.1469-8137.1979. tb02657.x

Elbert, W., Weber, B., Burrows, S., Steinkamp, J., Büdel, B., Andreae, M. O., et al. (2012). Contribution of cryptogamic covers to the global cycles of carbon and nitrogen. Nat. Geosci. 5:459. doi: 10.1038/ngeo1486

Ernst, W. (1990). Ecophysiology of plants in waterlogged and flooded environments. Aquat. Bot. 38, 73-90. doi: 10.1016/0304-3770(90)90099-7

Evans, R. O., and Fausey, N. R. (1999). Effects of inadequate drainage on crop growth and yield. Agric. Drainage 38, 13-54.

Feng, P., Wang, B., Liu, D. L., Xing, H., Ji, F., Macadam, I., et al. (2018). Impacts of rainfall extremes on wheat yield in semi-arid cropping systems in eastern Australia. Clim. Change 147, 555-569. doi: 10.1007/s10584-018-2170-x

Ferronato, C., Marinari, S., Francioso, O., Bello, D., Trasar-Cepeda, C., and Antisari, L. V. (2019). Effect of waterlogging on soil biochemical properties and organic matter quality in different salt marsh systems. Geoderma 338, 302-312. doi: 10.1016/j.geoderma.2018.12.019

Filipović, V., Mallmann, F. J. K., Coquet, Y., and Šimùnek, J. (2014). Numerical simulation of water flow in tile and mole drainage systems. Agric. Water Manag. 146, 105-114. doi: 10.1016/j.agwat.2014.07.020

Flowers, M., and Lal, R. (1998). Axle load and tillage effects on soil physical properties and soybean grain yield on a mollic ochraqualf in northwest Ohio. Soil Tillage Res. 48, 21-35. doi: 10.1016/S0167-1987(98) 00095-6

Folzer, H., Dat, J. F., Capelli, N., Rieffel, D., and Badot, P.-M. (2006). Response of sessile oak seedlings (Quercus petraea) to flooding: an integrated study. Tree Physiol. 26, 759-766. doi: 10.1093/treephys/26.6.759

Food and Agriculture Organization [FAO] (2002). Food and Agriculture Organization of the United Nations. Available at: http://www.fao.org/3/abc600e.pdf

Food and Agriculture Organization [FAO] (2015). Food and Agriculture Organization of the United Nations. Available at: http://www.fao.org/3/abc600e.pdf

Frank, M. (2010). Managing wet Soils - Mole Drainage (AG0949). Orange: Department of Primary Industries.

Gajri, P. R., Arora, V. K., and Chaudhary, M. R. (1994). Maize growth responses to deep tillage, straw mulching and farmyard manure in coarse textured soils of N.W. India. Soil Use Manage. 10, 15-19. doi: 10.1111/j.1475-2743.1994. tb00451.x

Gardner, B., Nielsen, D., and Shock, C. (1992). Infrared thermometry and the crop water stress index. I. History, theory, and baselines. J. Prod. Agric. 5, 462-466. doi: 10.2134/jpa1992.0462

Gardner, W., and Flood, R. (1993). Less waterlogging damage with long season wheats. Cereal Res. Commun. 21, 337-343.
Gasso, V., Oudshoorn, F. W., Sørensen, C. A., and Pedersen, H. H. (2014). An environmental life cycle assessment of controlled traffic farming. J. Cleaner Prod. 73, 175-182. doi: 10.1016/j.jclepro.2013.10.044

Gasso, V., Sørensen, C. A., Oudshoorn, F. W., and Green, O. (2013). Controlled traffic farming: A review of the environmental impacts. Eur. J. Agron. 48, 66-73. doi: 10.1111/j.1467-789X.2007.00432.x

Gechev, T., Gadjev, I., Van Breusegem, F., Inzé, D., Dukiandjiev, S., Toneva, V., et al. (2002). Hydrogen peroxide protects tobacco from oxidative stress by inducing a set of antioxidant enzymes. Cell. Mol. Life Sci. 59, 708-714. doi: $10.1007 / \mathrm{s} 00018-002-8459-\mathrm{x}$

Geigenberger, P. (2003). Response of plant metabolism to too little oxygen. Curr. Opin. Plant Biol. 6, 247-256. doi: 10.1016/S1369-5266(03)00038-4

Ghazouani, W., Molle, F., Swelam, A., Rap, E., and Abdo, A. (2015). Understanding Farmers' Adaptation to Water Scarcity: A Case Study from the Western Nile Delta. Pelawatte: IWMI.

Gibson, G. (2014). Utilising Innovative Management Techniques to Reduce Waterlogging. Moama, NSW: Nuffield Australia Farming Scholars.

Gill, J., Clark, G., Sale, P., Peries, R., and Tang, C. (2012). Deep placement of organic amendments in dense sodic subsoil increases summer fallow efficiency and the use of deep soil water by crops. Plant Soil 359, 57-69. doi: 10.1007/s11104-0121126-6

Gill, J., Sale, P., Peries, R., and Tang, C. (2009). Changes in soil physical properties and crop root growth in dense sodic subsoil following incorporation of organic amendments. Field Crops Res. 114, 137-146. doi: 10.1016/j.fcr.2009.07.018

Gill, M. B., Zeng, F., Shabala, L., Böhm, J., Zhang, G., Zhou, M., et al. (2018). The ability to regulate voltage-gated $\mathrm{K}+$-permeable channels in the mature root epidermis is essential for waterlogging tolerance in barley. J. Exp. Bot. 69, 667-680. doi: 10.1093/jxb/erx429

Glinski, J. (2018). Soil Physical Conditions and Plant Roots. Boca Raton, FL: CRC press. doi: 10.1201/9781351076708

Grains Research, and Development Corporation [GRDC] (2016). Understanding the Amelioration Processes of the Subsoil Application of Amendments in the Southern Region. Scoping Review for Project dav00149. Sri Lanka: GRDC.

Gramlich, A., Stoll, S., Stamm, C., Walter, T., and Prasuhn, V. (2018). Effects of artificial land drainage on hydrology, nutrient and pesticide fluxes from agricultural fields-A review. Agric. Ecosyst. Environ. 266, 84-99. doi: 10.1016/ j.agee.2018.04.005

Greenway, H., Armstrong, W., and Colmer, T. D. (2006). Conditions leading to high $\mathrm{CO} 2(>5 \mathrm{kPa})$ in waterlogged-flooded soils and possible effects on root growth and metabolism. Ann. Bot. 98, 9-32. doi: 10.1093/aob/mcl076

Guenette, K. G., and Hernandez-Ramirez, G. (2018). Tracking the influence of controlled traffic regimes on field scale soil variability and geospatial modeling techniques. Geoderma 328, 66-78. doi: 10.1016/j.geoderma.2018.04.026

Guo, W. Q., Chen, B. L., Liu, R. X., and Zhou, Z. G. (2010). Effects of nitrogen application rate on cotton leaf antioxidant enzyme activities and endogenous hormone contents under short-term waterlogging at flowering and bollforming stage. Yingyong Shengtai Xuebao 21, 53-60.

Gupta, S. (1997). Himalayan drainage patterns and the origin of fluvial megafans in the Ganges foreland basin. Geology 25, 11-14. doi: 10.1130/0091-7613(1997) 025<0011:HDPATO>2.3.CO;2

Gupta, S. (2002). A century of subsurface drainage research in India. Irrigation Drainage Syst. 16, 69-84. doi: 10.1023/A:10155254 05522

Habibzadeh, F., Sorooshzadeh, A., Pirdashti, H., and Modarres-Sanavy, S. A. M. (2013). Alleviation of waterlogging damage by foliar application of nitrogen compounds and tricyclazole in canola. Aust. J. Crop Sci. 7, 401-406.

Habibzadeh, F., Sorooshzadeh, A., Pirdashti, H., and Sanavy, S. (2012). Effect of nitrogen compounds and tricyclazole on some biochemical and morphological characteristics of waterlogged-canola. Int. Res. J. Appl. Basic Sci. 3, 77-84.

Hallard, M., and Armstrong, A. (1992). Observations of water movement to and within mole drainage channels. J. Agric. Eng. Res. 52, 309-315. doi: 10.1016/ 0021-8634(92)80069-5

Hamilton, G., Bakker, D., Houlebrook, D., and Spann, C. (2000). Raised beds prevent waterlogging and increase productivity. J. Dep. Agric. West. Aust. Ser. 4, 3-9.

Hamza, M., and Anderson, W. (2003). Responses of soil properties and grain yields to deep ripping and gypsum application in a compacted loamy sand soil 
contrasted with a sandy clay loam soil in Western Australia. Aust. J. Agric. Res. 54, 273-282. doi: 10.1071/AR02102

Hamza, M., and Anderson, W. (2005). Soil compaction in cropping systems: a review of the nature, causes and possible solutions. Soil Tillage Res. 82, 121-145. doi: 10.1016/j.still.2004.08.009

Henry, C. G., Sarzi Sartori, G. M., Gaspar, J. P., Marchesan, E., Hirsh, S. M., Horton, A. P., et al. (2018). Deep tillage and gypsum amendments on fully, deficit irrigated, and dryland soybean. Agron. J. 110, 737-748. doi: 10.2134/agronj2015. 11.0567

Herzog, M., Striker, G. G., Colmer, T. D., and Pedersen, O. (2016). Mechanisms of waterlogging tolerance in wheat-a review of root and shoot physiology. Plant Cell Environ. 39, 1068-1086. doi: 10.1111/pce. 12676

Heuperman, A. (2000). "Bio-drainage - an australian overview and two victorian case studies," in. Proceedings of the Eighth ICID International Drainage Workshop Role of Drainage and Challenges in 21st century, New Delhi, 1-16.

Heuperman, A., and Kapoor, A. (2003). Biodrainage Status in India and Other countries. New Delhi: Indian National Committee on Irrigation and Drainage, 147.

Hossain, M. A., and Uddin, S. N. (2011). Mechanisms of waterlogging tolerance in wheat: morphological and metabolic adaptations under hypoxia or anoxia. Aust. J. Crop Sci. 5, 1094-1101.

Huang, B., Johnson, J. W., Nesmith, S., and Bridges, D. C. (1994). Growth, physiological and anatomical responses of two wheat genotypes to waterlogging and nutrient supply. J. Exp. Bot. 45, 193-202. doi: 10.1093/jxb/45.2.193

Huang, X., Fan, Y., Shabala, L., Rengel, Z., Shabala, S., and Zhou, M. (2018). A major QTL controlling the tolerance to manganese toxicity in barley (Hordeum vulgare L.). Mol. Breed. 38:16.

Huang, X., Shabala, S., Shabala, L., Rengel, Z., Wu, X., Zhang, G., et al. (2015). Linking waterlogging tolerance with $\mathrm{Mn} 2+$ toxicity: a case study for barley. Plant Biol. 17, 26-33. doi: 10.1111/plb.12188

Hussain, I., Sohail, M., Tanveer, S. K., and Muneer, M. (2018). Impact of planting density and growth habit of genotypes on wheat yield under raised bed planting method. Science 37, 158-162.

Indraratna, B. (2017). "Recent advances in vertical drains and vacuum preloading for soft ground stabilisation," in, Proceedings of 19th International Conference on Soil Mechanics and Geotechnical Engineering, Seou, (London: International Society for Soil Mechanics and Geotechnical Engineering), 145-170.

Indraratna, B., Rujikiatkamjorn, C., and Sathananthan, I. (2005). Analytical and numerical solutions for a single vertical drain including the effects of vacuum preloading. Can. Geotech. J. 42, 994-1014. doi: 10.1139/t05-029

Intergovernmental Panel on Climate Change [IPCC] (2014). Climate Change 2014: Synthesis Report. Contribution of working groups I, II and III to the Fifth Assessment Report of the Intergovernmental Panel on Climate Change. Geneva: IPCC. doi: 10.1017/CBO9781107415416

Ishibashi, Y., Yamaguchi, H., Yuasa, T., Iwaya-Inoue, M., Arima, S., and Zheng, S.-H. (2011). Hydrogen peroxide spraying alleviates drought stress in soybean plants. J. Plant Physiol. 168, 1562-1567. doi: 10.1016/j.jplph.2011. 02.003

Jackson, M., and Colmer, T. (2005). Response and adaptation by plants to flooding stress. Ann. Bot. 96, 501-505. doi: 10.1093/aob/mci205

Jackson, M., and Hall, K. (1987). Early stomatal closure in waterlogged pea plants is mediated by abscisic acid in the absence of foliar water deficits. Plant Cell Environ. 10, 121-130.

Jackson, M., and Ricard, B. (2003). Physiology, Biochemistry and Molecular Biology of Plant Root Systems Subjected to Flooding of the Soil, in Root Ecology. Berlin: Springer, 193-213. doi: 10.1007/978-3-662-09784-7_8

Jaiswal, A., and Srivastava, J. (2018). Changes in reactive oxygen scavenging systems and protein profiles in maize roots in response to nitric oxide under waterlogging stress. Indian J. Biochem. Biophys. 55, 26-33.

Jisha, K., Vijayakumari, K., and Puthur, J. T. (2013). Seed priming for abiotic stress tolerance: an overview. Acta Physiol. Plant. 35, 1381-1396. doi: 10.1007/s11738012-1186-5

Jones, H. E., and Etherington, J. (1970). Comparative studies of plant growth and distribution in relation to waterlogging: I. The survival of Erica cinerea L. and E. tetralix L. and its apparent relationship to iron and manganese uptake in waterlogged soil. J. Ecol. 58, 487-496. doi: 10.2307/ 2258285
Kapoor, A. (2000). “Bio-drainage feasibility and principles of planning and design,” in Proceedings of the Eighth ICID International Drainage Workshop, (New Delhi: International Commission on Irrigation and Drainage), 17-32.

Kaur, G., Nelson, K., and Motavalli, P. (2018). Early-season soil waterlogging and N fertilizer sources impacts on corn $\mathrm{N}$ uptake and apparent $\mathrm{N}$ recovery efficiency. Agronomy 8:102. doi: 10.3390/agronomy8070102

Kaur, G., Zurweller, B. A., Nelson, K. A., Motavalli, P. P., and Dudenhoeffer, C. J. (2017). Soil waterlogging and nitrogen fertilizer management effects on corn and soybean yields. Agron. J. 109, 97-106. doi: 10.2134/agronj2016.07.0411

Kavian, A., Saleh, I., Habibnejad, M., and Jafarian, Z. (2018). Application of vegetative buffer strips under natural rainfall to conserve soil and water. Agriculture 64, 17-27.

Kawakami, E. M., Oosterhuis, D. M., and Snider, J. L. (2010). Physiological effects of 1-methylcyclopropene on well-watered and water-stressed cotton plants. J. Plant Growth Regul. 29, 280-288. doi: 10.1007/s00344-009-9134-3

Kazmi, S. I., Ertsen, M. W., and Asi, M. R. (2012). The impact of conjunctive use of canal and tube well water in Lagar irrigated area, Pakistan. Phys. Chem. Earth Parts A B C 47-48, 86-98. doi: 10.1016/j.pce.2012.01.001

Kijne, J. W. (2006). Abiotic stress and water scarcity: identifying and resolving conflicts from plant level to global level. Field Crops Res. 97, 3-18. doi: 10.1016/ j.fcr.2005.08.011

Kim, Y., Seo, C.-W., Khan, A. L., Mun, B.-G., Shahzad, R., Ko, J.-W., et al. (2018). Ethylene mitigates waterlogging stress by regulating glutathione biosynthesisrelated transcripts in soybeans. bioRxiv [Preprint]. doi: 10.1101/252312

King, K., Fausey, N., and Williams, M. (2014). Effect of subsurface drainage on streamflow in an agricultural headwater watershed. J. Hydrol. 519, 438-445. doi: 10.1016/j.jhydrol.2014.07.035

Kisaakye, E., Acuña, T. B., Johnson, P., and Shabala, S. (2017). "Improving wheat growth and nitrogen-use efficiency under waterlogged conditions," in Proceedings of the 18th Australian Agronomy Conference, Ballarat, 1-4.

Kisaakye, E., Botwright Acuna, T., Johnson, P., and Shabala, S. (2015). "Effect of water availability and nitrogen source on wheat growth and nitrogen-use efficiency," in Proceedings of the 17th Australian Society of Agronomy Conference, Hobart, 20-24.

Kolekar, O., Patil, S., and Rathod, S. (2014). Effects of different mole drain spacings on the yield of summer groundnut. Int. J. Res. Eng. Technol. 3, 2321-7308.

Konukcu, F., Gowing, J., and Rose, D. (2006). Dry drainage: a sustainable solution to waterlogging and salinity problems in irrigation areas? Agric. Water Manag. 83, 1-12. doi: 10.1016/j.agwat.2005.09.003

Kruseman, G. P., and Ridder, N. A. (1990). Analysis and evaluation of pumping test data. Anal. Eval. Pumping Test Data. 47:377.

Kuhwald, M., Blaschek, M., Brunotte, J., and Duttmann, R. (2017). Comparing soil physical properties from continuous conventional tillage with long-term reduced tillage affected by one-time inversion. Soil Use Manag. 33, 611-619. doi: $10.1111 /$ sum. 12372

Kumar, N. (2018). Effect of planting method on productivity and economics of sugarcane (Saccharum spp. hybrid complex) varieties under waterlogged condition. Indian Soc. Agron. 63, 95-99.

Laanbroek, H. (1990). Bacterial cycling of minerals that affect plant growth in waterlogged soils: a review. Aquat. Bot. 38, 109-125. doi: 10.1016/03043770(90)90101-P

Lal, S. K., Kumar, S., Sheri, V., Mehta, S., Varakumar, P., Ram, B., et al. (2018). "Seed priming: An emerging technology to impart abiotic stress tolerance in crop plants," in Advances in Seed Priming, eds A. Rakshit and H. Bahadur Singh (Singapore: Springer), 41-50. doi: 10.1007/978-981-130032-5 3

Lee, T., Jang, C., Kim, J., Seong, R., Kim, I., Kim, D., et al. (2007). Expressed sequence tags from wheat roots under hypoxia. Russ. J. Plant Physiol. 54, 659-668. doi: 10.1134/S1021443707050147

Lee, T. G., Jang, C. S., Kim, J. Y., Kim, D. S., Park, J. H., Kim, D. Y., et al. (2007). A Myb transcription factor (TaMyb1) from wheat roots is expressed during hypoxia: roles in response to the oxygen concentration in root environment and abiotic stresses. Physiol. Plant. 129, 375-385. doi: 10.1111/j.1399-3054.2006. 00828.x

Lerch, R. N., Lin, C. H., Goyne, K. W., Kremer, R. J., and Anderson, S. H. (2017). Vegetative buffer strips for reducing herbicide transport in runoff: effects of buffer width, vegetation, and season. J. Am. Water Resour. Assoc. 53, 667-683. doi: $10.1111 / 1752-1688.12526$ 
Leul, M., and Zhou, W. (1998). Alleviation of waterlogging damage in winter rape by application of uniconazole: effects on morphological characteristics, hormones and photosynthesis. Field Crops Res. 59, 121-127. doi: 10.1016/ S0378-4290(98)00112-9

Leul, M., and Zhou, W. (1999). Alleviation of waterlogging damage in winter rape by uniconazole application: effects on enzyme activity, lipid peroxidation, and membrane integrity. J. Plant Growth Regulation 18, 9-14. doi: 10.1007/ PL00007046

Li, H. B., Vaillancourt, R., Mendham, N., and Zhou, M. X. (2008). Comparative mapping of quantitative trait loci associated with waterlogging tolerance in barley (Hordeum vulgare L.). BMC Genomics 9:401. doi: 10.1186/1471-21649-401

Li, M.-F., Zhu, J.-Q., and Jiang, Z.-H. (2013). "Plant growth regulators and nutrition applied to cotton after waterlogging," in Proceedings of the Intelligent System Design and Engineering Applications (ISDEA), Third International Conference on, (Piscataway, NJ: IEEE), 1045-1048. doi: 10.1109/ISDEA. 2012.246

Li, W., Mo, W., Ashraf, U., Li, G., Wen, T., Abrar, M., et al. (2018). Evaluation of physiological indices of waterlogging tolerance of different maize varieties in South China. Appl. Ecol. Environ. Res. 16, 2059-2072. doi: 10.15666/aeer/1602_ 20592072

Li, Y., Tullberg, J., and Freebairn, D. (2007). Wheel traffic and tillage effects on runoff and crop yield. Soil Tillage Res. 97, 282-292. doi: 10.1016/j.still.2005. 10.001

Liao, M., Fillery, I. R., and Palta, J. A. (2004). Early vigorous growth is a major factor influencing nitrogen uptake in wheat. Funct. Plant Biol. 31, 121-129. doi: 10.1071/FP03060

Lin, C. H., Lerch, R. N., Goyne, K. W., and Garrett, H. E. (2011). Reducing herbicides and veterinary antibiotics losses from agroecoystems using vegetative buffers. J. Environ. Qual. 40, 791-799. doi: 10.2134/jeq2010.0141

Lin, K.-H. R., Tsou, C.-C., Hwang, S.-Y., Chen, L.-F. O., and Lo, H.-F. (2006). Paclobutrazol pre-treatment enhanced flooding tolerance of sweet potato. J. Plant Physiol. 163, 750-760. doi: 10.1016/j.jplph.2005.07.008

Linkemer, G., Board, J. E., and Musgrave, M. E. (1998). Waterlogging effects on growth and yield components in late-planted soybean. Crop Sci. 38, 1576-1584. doi: $10.2135 /$ cropsci1998.0011183X003800060028x

Lone, A. A., Khan, M. H., Dar, Z. A., and Wani, S. H. (2018). Breeding strategies for improving growth and yield under waterlogging conditions in maize: a review. Maydica 61:11.

Lorimer, R. (2008). The Adoption of GPS in Cropping Agriculture. Cleveland, OH: GPS.

Luan, H., Guo, B., Pan, Y., Lv, C., Shen, H., and Xu, R. (2018). Morpho-anatomical and physiological responses to waterlogging stress in different barley (Hordeum vulgare L.) genotypes. Plant Growth Regulation 85, 399-409. doi: 10.1007/ s10725-018-0401-9

Lubkowski, K., and Grzmil, B. (2007). Controlled release fertilizers. Pol. J. Chem. Technol. 9, 83-84. doi: 10.2478/v10026-007-0096-6

Ma, Y. L., Wang, H. F., Wang, P., Yu, C. G., Luo, S. Q., Zhang, Y. F., et al. (2018). Effects of cadmium stress on the antioxidant system and chlorophyll fluorescence characteristics of two Taxodium clones. Plant Cell Rep. 37, 1547-1555. doi: 10.1007/s00299-018-2327-0

MacEwan, R., Gardner, W., Ellington, A., Hopkins, D., and Bakker, A. (1992). Tile and mole drainage for control of waterlogging in duplex soils of south-eastern Australia. Aust. J. Exp. Agric. 32, 865-878. doi: 10.1071/EA9920865

Malano, H. M., and van Hofwegen, P. (2006). Management of Irrigation and Drainage Systems. London: CRC Press.

Malik, A. I., Colmer, T. D., Lambers, H., and Schortemeyer, M. (2001). Changes in physiological and morphological traits of roots and shoots of wheat in response to different depths of waterlogging. Funct. Plant Biol. 28, 1121-1131. doi: 10.1071/PP01089

Marashi, S. K. (2018). Evaluation of uptake rate and distribution of nutrient ions in wheat (Triticum aestivum L.) under waterlogging condition. Plant Physiol. 8, 2539-2547.

Masunaga, T., and Marques Fong, J. D. (2018). "Chapter 11 - strategies for increasing micronutrient availability in soil for plant uptake," in Plant Micronutrient Use Efficiency, eds M. A. Hossain, T. Kamiya, D. J. Burritt, L.-S. Phan Tran, and T. Fujiwara (Cambridge, MA: Academic Press), 195-208.
Matosic, S., Birkás, M., Vukadinovic, V., Kisic, I., and Bogunovic, I. (2018). Tillage, manure and gypsum use in reclamation of saline-sodic soils. Agric. Conspectus Sci. 83, 131-138.

McCaskill, M., and Kearney, G. (2016). Control of water leakage from below the root zone by summer-active pastures is associated with persistence, density and deep rootedness. Crop Pasture Sci. 67, 679-693. doi: 10.1071/CP15337

McDaniel, B. K., and Binder, B. M. (2012). Ethylene receptor1 (ETR1) is sufficient and has the predominant role in mediating inhibition of ethylene responses by silver in Arabidopsis thaliana. J. Biol. Chem. 112:383034.

McFarlane, D., and Cox, J. (1992). Management of excess water in duplex soils. Aust. J. Exp. Agric. 32, 857-864. doi: 10.1071/EA9920857

Miller, G., Shulaev, V., and Mittler, R. (2008). Reactive oxygen signaling and abiotic stress. Physiol. Plant. 133, 481-489. doi: 10.1111/j.1399-3054.2008.01090.x

Milroy, S. P., Bange, M. P., and Thongbai, P. (2009). Cotton leaf nutrient concentrations in response to waterlogging under field conditions. Field Crops Res. 113, 246-255. doi: 10.1016/j.fcr.2009.05.012

Misak, R., Baki, A. A., and El-Hakim, M. (1997). On the causes and control of the waterlogging phenomenon, Siwa Oasis, northern Western Desert, Egypt. J. Arid Environ. 37, 23-32. doi: 10.1006/jare.1997.0252

Monaghan, R., Paton, R., and Drewry, J. (2002). Nitrogen and phosphorus losses in mole and tile drainage from a cattle-grazed pasture in eastern Southland. N. Zealand J. Agric. Res. 45, 197-205. doi: 10.1080/00288233.2002.9513510

Monaghan, R., and Smith, L. (2004). Minimising surface water pollution resulting from farm-dairy effluent application to mole-pipe drained soils. II. The contribution of preferential flow of effluent to whole-farm pollutant losses in subsurface drainage from a West Otago dairy farm. N. Zealand J. Agric. Res. 47, 417-428. doi: 10.1080/00288233.2004.9513610

Mondal, T., Mitra, B., and Das, S. (2018). Precision nutrient management in wheat (Triticum aestivum) using Nutrient Expert ${ }^{\circledR}$ : Growth phenology, yield, nitrogen-use efficiency and profitability under eastern sub-Himalayan plains. Indian J. Agron. 63, 174-180.

Morales-Olmedo, M., Ortiz, M., and Sellés, G. (2015). Effects of transient soil waterlogging and its importance for rootstock selection. Chilean J. Agric. Res. 75, 45-56. doi: 10.4067/S0718-58392015000300006

Morard, P., and Silvestre, J. (1996). Plant injury due to oxygen deficiency in the root environment of soilless culture: a review. Plant Soil 184, 243-254. doi: $10.1007 / \mathrm{BF} 00010453$

Morling, R. (1982). Pros and Cons of Controlled Traffic Farming. ASAE Paper 82-1043. Washington, DC: ASAE.

Muirhead, W., Humphreys, E., Jayawardane, N., and Moll, J. (1996). Shallow subsurface drainage in an irrigated vertisol with a perched water table. Agric. Water Manag. 30, 261-282. doi: 10.1016/0378-3774(95)01225-7

Muñoz-Carpena, R., Fox, G. A., Ritter, A., Perez-Ovilla, O., and RodeaPalomares, I. (2018). Effect of vegetative filter strip pesticide residue degradation assumptions for environmental exposure assessments. Sci. Total Environ. 619, 977-987. doi: 10.1016/j.scitotenv.2017.11.093

Muñoz-Carpena, R., Fox, G. A., and Sabbagh, G. J. (2010). Parameter importance and uncertainty in predicting runoff pesticide reduction with filter strips. J. Environ. Qual. 39, 630-641. doi: 10.2134/jeq2009.0300

Mustafa, H. S. B., Mahmood, T., Ullah, A., Sharif, A., Bhatti, A. N., Muhammad Nadeem, M., et al. (2017). Role of seed priming to enhance growth and development of crop plants against biotic and abiotic stresses. Bull. Biol. Allied Sci. Res. 2, 1-11.

Najeeb, U., Bange, M. P., Tan, D. K., and Atwell, B. J. (2015). Consequences of waterlogging in cotton and opportunities for mitigation of yield losses. AoB Plants 7:lv080. doi: 10.1093/aobpla/plv080

Najeeb, U., Tan, D., Bange, M., and Atwell, B. (2017). "Stress-induced fruit abscission in cotton and role of ethylene," in Proceedings of the 18th Australian Agronomy Conference, (Ballarat VIC: Australian Society of Agronomy), 1-4.

Najeeb, U., Tan, D. K., Bange, M. P., and Atwell, B. J. (2018). Protecting cotton crops under elevated $\mathrm{CO} 2$ from waterlogging by managing ethylene. Funct. Plant Biol. 45, 340-349. doi: 10.1071/FP17184

Negusse, T., Yazew, E., and Tadesse, N. (2013). Quantification of the impact of integrated soil and water conservation measures on groundwater availability in Mendae Catchment, Abraha We-Atsebaha, eastern Tigray, Ethiopia. Momona Ethiopian J. Sci. 5, 117-136.

Nguyen, H. C., Lin, K. H., Ho, S. L., Chiang, C. M., and Yang, C. M. (2018). Enhancing the abiotic stress tolerance of plants: From chemical treatment to 
biotechnological approaches. Physiol. plant. 164, 452-466. doi: 10.1111/ppl. 12812

Nguyen, L. T., Osanai, Y., Anderson, I. C., Bange, M. P., Tissue, D. T., and Singh, B. K. (2018). Flooding and prolonged drought have differential legacy impacts on soil nitrogen cycling, microbial communities and plant productivity. Plant Soil 431, 371-387. doi: 10.1007/s11104-018-3774-7

Nguyen, T. N., Tuan, P. A., Mukherjee, S., Son, S., and Ayele, B. T. (2018). Hormonal regulation in adventitious roots and during their emergence under waterlogged conditions in wheat. J. Exp. Bot. 69, 4065-4082. doi: 10.1093/jxb/ ery190

Nichols, P. (2018). Yanco Subterranean Clover. Orange: Department of Primary Industries and Regional Development (DPIRD).

Nicholson, C. (2016). "Business case for investment in subsoil modification with organic material," in Prepared for Southern Farming Systems, As Part of the National Landcare project, INNOV-108, (St, Inverleigh VIC: Southern Farming Systems (SFS)).

Noreen, S., Fatima, Z., Ahmad, S., and Ashraf, M. (2018). Foliar Application of Micronutrients in Mitigating Abiotic Stress in Crop Plants Plant Nutrients and Abiotic Stress Tolerance. Singapore: Springer, 95-117. doi: 10.1007/978-981-109044-8_3

Pagliai, M., Vignozzi, N., and Pellegrini, S. (2004). Soil structure and the effect of management practices. Soil Tillage Res. 79, 131-143. doi: 10.1016/j.still.2004. 07.002

Palla, A., Colli, M., Candela, A., Aronica, G., and Lanza, L. (2018). Pluvial flooding in urban areas: the role of surface drainage efficiency. J. Flood Risk Manag. 11, S663-S676. doi: 10.1111/jfr3.12246

Pandey, D., Goswami, C., Kumar, B., and Jain, S. (2002). Effect of growth regulators on photosynthetic metabolites in cotton under water stress. Biol. Plant. 45, 445-448. doi: 10.1023/A:1016286121451

Pang, J., Cuin, T., Shabala, L., Zhou, M., Mendham, N., and Shabala, S. (2007a). Effect of secondary metabolites associated with anaerobic soil conditions on ion fluxes and electrophysiology in barley roots. Plant Physiol. 145, 266-276.

Pang, J., Ross, J., Zhou, M., Mendham, N., and Shabala, S. (2007b). Amelioration of detrimental effects of waterlogging by foliar nutrient sprays in barley. Funct. Plant Biol. 34, 221-227. doi: 10.1071/FP06158

Pang, J., Zhou, M., Mendham, N., and Shabala, S. (2004). Growth and physiological responses of six barley genotypes to waterlogging and subsequent recovery. Aust. J. Agric. Res. 55, 895-906. doi: 10.1071/AR03097

Pang, J. Y., Newman, I., Mendham, N., Zhou, M., and Shabala, S. (2006). Microelectrode ion and $\mathrm{O} 2$ fluxes measurements reveal differential sensitivity of barley root tissues to hypoxia. Plant Cell Environ. 29, 1107-1121. doi: 10. 1111/j.1365-3040.2005.01486.x

Parent, C., Capelli, N., Berger, A., Crèvecoeur, M., and Dat, J. F. (2008). An overview of plant responses to soil waterlogging. Plant Stress 2, 20-27.

Perata, P., Armstrong, W., and Voesenek, L. A. (2011). Plants and flooding stress. N. Phytol. 190, 269-273. doi: 10.1111/j.1469-8137.2011.03702.x

Pereira, E. I, Nogueira, A. A. R., Cruz, C. C., Guimarapes, G. G., Foschini, M. M., Bernardi, A. C., et al. (2017). Controlled urea release employing nanocomposites increases the efficiency of nitrogen use by forage. ACS Sustain. Chem. Eng. 5, 9993-10001. doi: 10.1021/acssuschemeng.7b01919

Pérez-Jiménez, M., Hernández-Munuera, M., Piñero, M. C., López-Ortega, G., and del Amor, F. M. (2018). Are commercial sweet cherry rootstocks adapted to climate change? Short-term waterlogging and $\mathrm{CO} 2$ effects on sweet cherry cv.'Burlat'. Plant Cell Environ. 41, 908-918. doi: 10.1111/pce.12920

Peries, R. (2013). Subsoil Manuring: An Innovative Approach To Addressing Subsoil Problems Targeting Higher Water Use Efficiency In Southern Australia. St, Inverleigh VIC: Southern Farming Systems.

Petrov, V., Hille, J., Mueller-Roeber, B., and Gechev, T. S. (2015). ROS-mediated abiotic stress-induced programmed cell death in plants. Front. Plant Sci. 6:69. doi: $10.3389 /$ fpls.2015.00069

Pierret, A., Doussan, C., Capowiez, Y., and Bastardie, F. (2007). Root functional architecture: a framework for modeling the interplay between roots and soil. Vadose Zone J. 6, 269-281. doi: 10.2136/vzj2006. 0067

Ploschuk, R. A., Miralles, D. J., Colmer, T. D., Ploschuk, E. L., and Striker, G. G. (2018). Waterlogging of winter crops at early and late stages: impacts on leaf physiology, growth and yield. Front. Plant Sci. 9:1863. doi: 10.3389/fpls.2018. 01863
Ponnamperuma, F. (1984). "Effects of flooding on soils," in Flooding and Plant Growth, ed. T. T. Kozlowski (Cambridge, MA: Academic Press), 9-45. doi: 10.1016/B978-0-12-424120-6.50007-9

Prathapar, S., Rajmohan, N., Sharma, B., and Aggarwal, P. (2018). Vertical drains to minimize duration of seasonal waterlogging in Eastern Ganges Basin flood plains: a field experiment. Nat. Hazards 92, 1-17. doi: 10.1007/s11069-0183188-0

Price, P. (2004). Spreading the PA Message. Canberra, ACT: Grains Research and Development Corporation.

Pujol, V., and Wissuwa, M. (2018). Contrasting development of lysigenous aerenchyma in two rice genotypes under phosphorus deficiency. BMC Res. Notes 11:60. doi: 10.1186/s13104-018-3179-y

Pulford, I., and Tabatabai, M. (1988). Effect of waterlogging on enzyme activities in soils. Soil Biol. Biochem. 20, 215-219. doi: 10.1016/0038-0717(88) 90039-9

Qingjie, W., Hao, C., Hongwen, L., Wenying, L., Xiaoyan, W., McHugh, A. D., et al. (2009). Controlled traffic farming with no tillage for improved fallow water storage and crop yield on the Chinese Loess Plateau. Soil Tillage Res. 104, 192-197. doi: 10.1016/j.still.2008.10.012

Qiu, J. (1991). Study on determination of wet tolerance of 4572 barley germplasm resources. Acta Agric. Shanghai 7, 27-32.

Rademacher, W. (2015). Plant growth regulators: backgrounds and uses in plant production. J. Plant Growth Regulation 34, 845-872. doi: 10.1007/s00344-0159541-6

Rajaeian, S., and Ehsanpour, A. (2015). Physiological responses of tobacco plants (Nicotiana rustica) pretreated with ethanolamine to salt stress. Russ. J. Plant Physiol. 62, 246-252. doi: 10.1134/S1021443715020156

Ram, J., Garg, V., Toky, O., Minhas, P., Tomar, O., Dagar, J., et al. (2007). Biodrainage potential of Eucalyptus tereticornis for reclamation of shallow water table areas in north-west India. Agrofor. Syst. 69, 147-165. doi: 10.1007/ s10457-006-9026-5

Rao, R., Li, Y., Bryan, H. H., Reed, S. T., and D'AMBROSIO, F. (2002). "Assessment of foliar sprays to alleviate flooding injury in corn (Zea mays L.)," in Proceedings of the Florida State Horticultural Society, (Lake Alfred: Florida State Horticultural Society), 208-211.

Raper, R. (2005). Agricultural traffic impacts on soil. J. Terramech. 42, 259-280. doi: 10.1016/j.jterra.2004.10.010

Rasaily, R. G., Li, H., He, J., Wang, Q., and Lu, C. (2012). Influence of no tillage controlled traffic system on soil physical properties in double cropping area of North China plain. Afr. J. Biotechnol. 11, 856-864.

Rasheed, R., Iqbal, M., Ashraf, M. A., Hussain, I., Shafiq, F., Yousaf, A., et al. (2018). Glycine betaine counteracts the inhibitory effects of waterlogging on growth, photosynthetic pigments, oxidative defence system, nutrient composition, and fruit quality in tomato. J. Hortic. Sc. Biotechnol. 93, 385-391. doi: 10.1080/ 14620316.2017.1373037

Rebetzke, G., Botwright, T., Moore, C., Richards, R., and Condon, A. (2004). Genotypic variation in specific leaf area for genetic improvement of early vigour in wheat. Field Crops Res. 88, 179-189. doi: 10.1016/j.fcr.2004.01.007

Reddy, K., and Patrick, W. H. Jr. (1975). Effect of alternate aerobic and anaerobic conditions on redox potential, organic matter decomposition and nitrogen loss in a flooded soil. Soil Biol. Biochem. 7, 87-94. doi: 10.1016/0038-0717(75) 90004-8

Ren, B., Zhang, J., Dong, S., Liu, P., and Zhao, B. (2018). Exogenous 6benzyladenine improves antioxidative system and carbon metabolism of summer maize waterlogged in the field. J. Agron. Crop Sci. 204, 175-184. doi: $10.1111 /$ jac. 12253

Ren, B., Zhu, Y., Zhang, J., Dong, S., Liu, P., and Zhao, B. (2016). Effects of spraying exogenous hormone 6-benzyladenine (6-BA) after waterlogging on grain yield and growth of summer maize. Field Crops Res. 188, 96-104. doi: $10.1016 /$ j.fcr.2015.10.016

Rengasamy, P. (2006). World salinization with emphasis on Australia. J. Exp. Bot. 57, 1017-1023. doi: 10.1093/jxb/erj108

Renton, M., and Flower, K. C. (2015). Occasional mouldboard ploughing slows evolution of resistance and reduces long-term weed populations in no-till systems. Agric. Syst. 139, 66-75. doi: 10.1016/j.agsy.2015.06.005

Riffkin, P., Evans, P., Chin, J., and Kearney, G. (2003). Early-maturing spring wheat outperforms late-maturing winter wheat in the high rainfall environment of south-western Victoria. Aust. J. Agric. Res. 54, 193-202. doi: 10.1071/AR02081 
Rincon-Florez, V. A., Dang, Y. P., Crawford, M. H., Schenk, P. M., and Carvalhais, L. C. (2016). Occasional tillage has no effect on soil microbial biomass, activity and composition in Vertisols under long-term no-till. Biol. Fertil. Soils 52, 191-202. doi: 10.1007/s00374-015-1066-4

Ritzema, H., Satyanarayana, T., Raman, S., and Boonstra, J. (2008). Subsurface drainage to combat waterlogging and salinity in irrigated lands in India: lessons learned in farmers' fields. Agric. Water Manag. 95, 179-189. doi: 10.1016/j. agwat.2007.09.012

Robertson, D., Zhang, H., Palta, J. A., Colmer, T., and Turner, N. C. (2009). Waterlogging affects the growth, development of tillers, and yield of wheat through a severe, but transient, $\mathrm{N}$ deficiency. Crop Pasture Sci. 60, 578-586. doi: $10.1071 / \mathrm{CP} 08440$

Robertson, M. (2008). The Economics of Precision. Grains Research Update: Northern Region. New South Wales: Grains Research and Development Corporation.

Robertson, M., Carberry, P., and Brennan, L. (2007). The Economic Benefits of Precision Agriculture: Case Studies From Australian Grain Farms. Available at: https:/grdc.com.au/resources-and-publications/grdc-update-papers/ tab-content/grdc-update-papers/2008/02/economic-benefits-of-precisionagriculture-case-studies-from-australian-grain-farms

Robinson, M., Mulqueen, J., and Burke, W. (1987). On flows from a clay soilseasonal changes and the effect of mole drainage. J. Hydrol. 91, 339-350. doi: 10.1016/0022-1694(87)90210-1

Rochester, I., Peoples, M., Hulugalle, N., Gault, R., and Constable, G. (2001). Using legumes to enhance nitrogen fertility and improve soil condition in cotton cropping systems. Field Crops Res. 70, 27-41. doi: 10.1016/S0378-4290(00) 00151-9

Romina, P., Abeledo, L. G., and Miralles, D. J. (2018). Physiological traits associated with reductions in grain number in wheat and barley under waterlogging. Plant Soil 429, 1-13.

Roper, M. M., Davies, S. L., Blackwell, P. S., Hall, D. J. M., Bakker, D. M., Jongepier, R., et al. (2015). Management options for water-repellent soils in Australian dryland agriculture. Soil Res. 53, 786-806. doi: 10.1071/SR14330

Roth, C. H., Fischer, R. A., Piggin, C., and Meyer, W. (2005). Evaluation and Performance of Permanent Raised Bed Systems in Asia, Mexico and Australia: A Synopsis Griffith, NSW: Australia and Mexico: 200-208.

Roy Chowdhury, S., Kumar, A., Brahmanand, P., Ghosh, S., Mohanty, R., Jena, S., et al. (2011). Application of Bio-Drainage for Reclamation of Waterlogged Situations in Deltaic Orissa. Research Bulletin 53. Bhubaneswar: Directorate of Water Management.

Saadat, S., Bowling, L., Frankenberger, J., and Kladivko, E. (2018). Nitrate and phosphorus transport through subsurface drains under free and controlled drainage. Water Res. 142, 196-207. doi: 10.1016/j.watres.2018.05.040

Sairam, R., Kumutha, D., Ezhilmathi, K., Chinnusamy, V., and Meena, R. (2009). Waterlogging induced oxidative stress and antioxidant enzyme activities in pigeon pea. Biol. Plant. 53, 493-504. doi: 10.1007/s10535-0090090-3

Sale, P. (2014). Final report for ULA00008 Validating subsoil manuring in the High Rainfall Zone in Victoria (VIC). Barton ACT: GRDC.

Saleh, I., Kavian, A., Roushan, M. H., and Jafarian, Z. (2018). The efficiency of vegetative buffer strips in runoff quality and quantity control. Int. J. Environ. Sci. Technol. 15, 811-820. doi: 10.1007/s13762-0171411-2

Sarkar, A., Banik, M., Ray, R., and Patra, S. (2018). Soil moisture and groundwater dynamics under biodrainage vegetation in a waterlogged land. Int. J. Pure Appl. Biosci. 6, 1225-1233. doi: 10.18782/2320-7051.6052

Sarkar, R., Reddy, J., Sharma, S., and Ismail, A. M. (2006). Physiological basis of submergence tolerance in rice and implications for crop improvement. Curr. Sci. 91, 899-906.

Savvides, A., Ali, S., Tester, M., and Fotopoulos, V. (2016). Chemical priming of plants against multiple abiotic stresses: mission possible? Trends Plant Sci. 21, 329-340. doi: 10.1016/j.tplants.2015.11.003

Sayed, S. A. (1998). Impacts of boron application on maize plants growing under flooded and unflooded conditions. Biol. Plant. 41, 101-109. doi: 10.1023/A: 1001720702268

Scanlan, C. A., and Davies, S. L. (2019). Soil mixing and redistribution by strategic deep tillage in a sandy soil. Soil Tillage Res. 185, 139-145. doi: 10.1016/j.still. 2018.09.008
Schmidt, E., and Zemadim, B. (2015). Expanding sustainable land management in Ethiopia: scenarios for improved agricultural water management in the Blue Nile. Agric. Water Manag. 158, 166-178. doi: 10.1016/j.agwat.2015.05.001

Schneider, F., Don, A., Hennings, I., Schmittmann, O., and Seidel, S. J. (2017). The effect of deep tillage on crop yield-What do we really know? Soil Tillage Res. 174, 193-204. doi: 10.1016/j.still.2017.07.005

Setter, T., and Belford, B. (1990). Waterlogging: how it reduces plant growth and how plants can overcome its effects. J. Dep. Agric. West. Aust. Ser. 4, 51-55.

Setter, T., and Waters, I. (2003). Review of prospects for germplasm improvement for waterlogging tolerance in wheat, barley and oats. Plant Soil 253, 1-34. doi: 10.1023/A:1024573305997

Shabala, S. (2011). Physiological and cellular aspects of phytotoxicity tolerance in plants: the role of membrane transporters and implications for crop breeding for waterlogging tolerance. N. Phytol. 190, 289-298. doi: 10.1111/j.1469-8137. 2010.03575.x

Shabala, S., White, R. G., Djordjevic, M. A., Ruan, Y.-L., and Mathesius, U. (2016). Root-to-shoot signalling: integration of diverse molecules, pathways and functions. Funct. Plant Biol. 43, 87-104. doi: 10.1071/ FP15252

Shahrayini, E., Fallah, M., Shabanpour, M., Ebrahimi, E., and Saadat, S. (2018). Investigation of soil compaction on yield and agronomic traits of wheat under saline and non-saline soils. Arch. Agron. Soil Sci. 64:10. doi: 10.1080/03650340. 2018.1431832

Sharma, S. K., Kulshreshtha, N., Kumar, A., Yaduvanshi, N. P. S., Singh, M., Prasad, K. R. K., et al. (2018). Waterlogging effects on elemental composition of wheat genotypes in sodic soils. J. Plant Nutr. 41, 1252-1262. doi: 10.1080/01904167. 2018.1434541

Shaviv, A. (2001). Advances in controlled-release fertilizers. Adv. Agron. 71, 1-49. doi: 10.1016/S0065-2113(01)71011-5

Shaxson, F., and Barber, R. (2003). Optimizing Soil Moisture For Plant Production: The Significance Of Soil Porosity. Rome: UN-FAO.

Shoji, S., Delgado, J., Mosier, A., and Miura, Y. (2001). Use of controlled release fertilizers and nitrification inhibitors to increase nitrogen use efficiency and to conserve air andwater quality. Commun. Soil Sci. Plant Anal. 32, 1051-1070. doi: 10.1081/CSS-100104103

Silberstein, R., Vertessy, R., Morris, J., and Feikema, P. (1999). Modelling the effects of soil moisture and solute conditions on long-term tree growth and water use: a case study from the Shepparton irrigation area, Australia. Agric. Water Manag. 39, 283-315. doi: 10.1016/S0378-3774(98)00083-3

Silva, D. M. D., Fonte, N. D. S. D., Souza, K. R. D. D., Rodrigues-Brandão, I., Alves, I. T. L., and Donizeti, J. (2017). Relationship between manganese toxicity and waterlogging tolerance in Zea mays L. cv. Saracura. Acta Sci. Agron. 39, 75-82. doi: 10.4025/actasciagron.v39i1.30997

Singh, A. (2012). Development and application of a watertable model for the assessment of waterlogging in irrigated semi-arid regions. Water Resour. Manag. 26, 4435-4448. doi: 10.1007/s11269-012-0154-6

Singh, A. (2016). Hydrological problems of water resources in irrigated agriculture: A management perspective. J. Hydrol. 541, 1430-1440. doi: 10.1016/j.jhydrol. 2016.08.044

Singh, A. (2018a). Managing the salinization and drainage problems of irrigated areas through remote sensing and GIS techniques. Ecol. Indic. 89, 584-589. doi: 10.1016/j.ecolind.2018.02.041

Singh, A. (2018b). Salinization of agricultural lands due to poor drainage: A viewpoint. Ecol. Indic. 95, 127-130. doi: 10.1016/j.ecolind.2018.07.037

Singh, A., and Panda, S. N. (2012). Integrated salt and water balance modeling for the management of waterlogging and salinization. I: validation of SAHYSMOD. J. Irrigation Drainage Eng. 138, 955-963. doi: 10.1061/(ASCE)IR.1943-4774. 0000511

Singh, G., and Lal, K. (2018). Review and case studies on biodrainage: An alternative drainage system to manage waterlogging and salinity. Irrigation Drainage 67, 51-64. doi: 10.1002/ird.2252

Singh, S. P., and Setter, T. L. (2017). Effect of waterlogging on element concentrations, growth and yield of wheat varieties under farmer's sodic field conditions. Proc. Natl. Acad. Sci. India Section B Biol. Sci. 87, 513-520. doi: 10.1007/s40011-015-0607-9

Smedema, L. K., Vlotman, W. F., and Rycroft, D. (2014). Modern Land Drainage: Planning, Design and Management of Agricultural Drainage Systems. Boca Raton, FL: CRC Press. 
Sojka, R., and Scott, H. (2002). Aeration Measurement Encyclopedia of Soil Science, 1st Edn. New York, NY: Marcel Dekker, Inc, 27-29.

Solaiman, Z., Colmer, T., Loss, S., Thomson, B., and Siddique, K. (2007). Growth responses of cool-season grain legumes to transient waterlogging. Aust. J. Agric. Res. 58, 406-412. doi: 10.1071/AR06330

Soomro, U. A., Rahman, M. U., Odhano, E. A., Gul, S., and Tareen, A. Q. (2009). Effects of sowing method and seed rate on growth and yield of wheat (Triticum aestivum). World J. Agric. Sci. 5, 159-162.

Stapper, M., and Harris, H. (1989). Assessing the productivity of wheat genotypes in a Mediterranean climate, using a crop-simulation model. Field Crops Res. 20, 129-152. doi: 10.1016/0378-4290(89)90057-9

Striker, G. (2008). Visiting the methodological aspects of flooding experiments: Quantitative evidence from agricultural and ecophysiological studies. J. Agron. Crop Sci. 194, 249-255. doi: 10.1111/j.1439-037X.2008.00317.x

Sudama, S., Tiwari, T. N., Srivastava, R. P., Singh, G. P., and Singh, S. (1998). Effect of potassium on stomatal behaviour, yield and juice quality of sugarcane under moisture stress condition. Indian J. Plant Physiol. 3, 303-305.

Sundgren, T. K., Uhlen, A. K., Lillemo, M., Briese, C., and Wojciechowski, T. (2018). Rapid seedling establishment and a narrow root stele promotes waterlogging tolerance in spring wheat. J. Plant Physiol. 227, 45-55. doi: 10. 1016/j.jplph.2018.04.010

Swarup, A., and Sharma, D. (1993). Influence of top-dressed nitrogen in alleviating adverse effects of flooding on growth and yield of wheat in a sodic soil. Field Crops Res. 35, 93-100. doi: 10.1016/0378-4290(93)90142-A

Takeda, K., and Fukuyama, T. (1986). Variation and Geographical Distribution Of Varieties For Flooding Tolerance In Barley Seeds. Okayama: Barley Genetics Newsletter.

Tanji, K. K. (1990). "Nature and extent of agricultural salinity. agricultural salinity assessment and management," in ASCE Manuals and Reports on Engineering Practice No. 671, ed. K. K. Tanji (New York, NY: American Society of Civil Engineers), 619.

Taylor, J. (1992). Reduction of traffic-induced soil compaction. Soil Tillage Res. 24, 301-302. doi: 10.1016/0167-1987(92)90115-R

Taylor, J. H. (1983). Benefits of permanent traffic lanes in a controlled traffic crop production system. Soil Tillage Res. 3, 385-395. doi: 10.1016/0167-1987(83) 90040-5

Teixeira, D. L., de Matos, A. T., de Matos, M. P., Miranda, S. T., and Vieira, D. P. (2018). Evaluation of the effects of drainage and different rest periods as techniques for unclogging the porous medium in horizontal subsurface flow constructed wetlands. Ecol. Eng. 120, 104-108. doi: 10.1016/j.ecoleng.2018. 05.042

Tewari, S., and Mishra, A. (2018). Flooding Stress in Plants and Approaches to Overcome Plant Metabolites and Regulation Under Environmental Stress. New York,NY: Elsevier, 355-366. doi: 10.1016/B978-0-12-812689-9. 00018-2

Thomsen, M. N., Tamirat, T. W., Pedersen, S. M., Lind, K. M., Pedersen, H. H., de Bruin, S., et al. (2018). "Farmers' perception of Controlled Traffic Farming (CTF) and associated technologies (No. 2018/12)," in IFRO Working Paper (Copenhagen: University of Copenhagen).

Tian, S., Fischer, M., Chescheir, G. M., Youssef, M. A., Cacho, J. F., and King, J. S. (2018). Microtopography-induced transient waterlogging affects switchgrass (Alamo) growth in the lower coastal plain of North Carolina, USA. GCB Bioenergy 10, 577-591. doi: 10.1111/gcbb.12510

Tilman, D., Cassman, K. G., Matson, P. A., Naylor, R., and Polasky, S. (2002). Agricultural sustainability and intensive production practices. Nature 418, 671-677. doi: 10.1038/nature01014

Trenkel, M. E. (2010). Slow-and Controlled-Release and Stabilized Fertilizers: An Option for Enhancing Nutrient Use Efficiency in Agriculture. Paris: International fertilizer industry association.

Trought, M., and Drew, M. (1980). The development of waterlogging in wheat seedlings. I. Shoot and root growth in relation to changes in the concentration of dissolved gases and solutes in the soil solution. Plant Soil 54, 77-94. doi: 10.1007/BF02182001

Tullberg, J. (2000). Wheel traffic effects on tillage draught. J. Agric. Eng. Res. 75, 375-382. doi: 10.1006/jaer.1999.0516

Tullberg, J., Yule, D., and McGarry, D. (2007). Controlled traffic farming-from research to adoption in Australia. Soil Tillage Res. 97, 272-281. doi: 10.1016/j. still.2007.09.007
Tuohy, P., Humphreys, J., Holden, N., and Fenton, O. (2015). "Mole drainage performance in a clay loam soil," in NJF Congress: Nordic view to sustainable rural development, (Riga: NJF).

Tuohy, P., Humphreys, J., Holden, N., and Fenton, O. (2016). Runoff and subsurface drain response from mole and gravel mole drainage across episodic rainfall events. Agric. Water Manag. 169, 129-139. doi: 10.1016/j.agwat.2016. 02.020

Tuohy, P., O'Loughlin, J., and Fenton, O. (2018). Modeling performance of a tile drainage system incorporating mole drainage. Trans. ASABE 61, 169-178. doi: $10.13031 /$ trans. 12203

Unger, P. W., Sharpley, A. N., Steiner, J. L., Papendick, R. I., and Edwards, W. M. (2018). Soil Management Research for Water Conservation and Quality, Advances in Soil and Water Conservation. Abingdon: Routledge, 69-98. doi: 10.1201/9781315136912-5

Varadachari, C., and Goertz, H. M. (2010). "Slow-release and controlled-release nitrogen fertilizers," in ING Bulletins on Regional Assessment of Reactive Nitrogen. ed. S. Bijay (New Delhi: SCON-ING).

Velmurugan, A., Swarnam, T., Ambast, S., and Kumar, N. (2016). Managing waterlogging and soil salinity with a permanent raised bed and furrow system in coastal lowlands of humid tropics. Agric. Water Manag. 168, 56-67. doi: 10.1016/j.agwat.2016.01.020

Vwioko, E., Adinkwu, O., and El-Esawi, M. A. (2017). Comparative physiological, biochemical, and genetic responses to prolonged waterlogging stress in okra and maize given exogenous ethylene priming. Front. Physiol. 8:632. doi: 10.3389/ fphys.2017.00632

Wani, S. H., Choudhary, M., Kumar, P., Akram, N. A., Surekha, C., Ahmad, P., et al. (2018). "Marker-assisted breeding for abiotic stress tolerance in crop plants," in Biotechnologies of Crop Improvement, eds S. Gosal and S. Wani (Cham: Springer), 3 .

Ward, A., Johnston, T., Watson, D., and Jenkin, T. (2007).

Ward, A., Sharpley, A., Miller, K., Dick, W., Hoorman, J., Fulton, J., et al. (2018). An assessment of in-field nutrient best management practices for agricultural crop systems with subsurface drainage. J. Soil Water Conser. 73, 5A-10A. doi: $10.2489 /$ jswc.73.1.5A

Watson, E., Lapins, P., and Barron, R. (1976). Effect of waterlogging on the growth, grain and straw yield of wheat, barley and oats. Aust. J. Exp. Agric. 16, 114-122. doi: 10.1071/EA9760114

Webb, B., Blackwell, P., Riethmuller, G., and Lemon, J. (2004). Tramline Farming Systems: Technical Manual. State of Western: DAFWA.

Weber, B., and Hill, J. (2016). Remote Sensing of Biological Soil Crusts at Different Scales Biological Soil Crusts: An Organizing Principle in Drylands. Berlin: Springer, 215-234. doi: 10.1007/978-3-319-30214-0_12

Williams, M., King, K., and Fausey, N. (2015). Drainage water management effects on tile discharge and water quality. Agric. Water Manag. 148, 43-51. doi: 10. 1016/j.agwat.2014.09.017

Wollmer, A. C., Pitann, B., and Mühling, K. H. (2018). Nutrient deficiencies do not contribute to yield loss after waterlogging events in winter wheat (Triticum aestivum). Ann. Appl. Biol. 173, 141-153. doi: 10.1111/aab. 12449

Wu, H., Xiang, J., Chen, H., Zhang, Y., Zhang, Y., and Zhu, F. (2018). Effects of exogenous growth regulators on plant elongation and carbohydrate consumption of rice seedlings under submergence. J. Appl. Ecol. 29, 149-157. doi: 10.13287/j.1001-9332.201801.021

Wu, X., Tang, Y., Li, C., McHugh, A., Li, Z., and Wu, C. (2018). Individual and combined effects of soil waterlogging and compaction on physiological characteristics of wheat in southwestern China. Field Crops Res. 215, 163-172. doi: $10.1016 /$ j.fcr.2017.10.016

Wu, Q.-X., Zhu, J.-Q., Liu, K.-W., and Chen, L.-G. (2012). Effects of fertilization on growth and yield of cotton after surface waterlogging elimination. Adv. J. Food Sci. Technol. 4, 398-403.

Xian, C., Qi, Z., Tan, C. S., and Zhang, T.-Q. (2017). Modeling hourly subsurface drainage using steady-state and transient methods. J. Hydrol. 550, 516-526. doi: 10.1016/j.jhydrol.2017.05.016

Xiao, Y.-P., Wei, K., Chen, J.-X., Zhou, M.-X., and Zhang, G.-P. (2007). Genotypic difference in growth inhibition and yield loss of barley under waterlogging stress. Agric. Life Sci. 33, 525-532.

Yaduvanshi, N., Setter, T., Sharma, S., Singh, K., and Kulshreshtha, N. (2012). Influence of waterlogging on yield of wheat (Triticum aestivum), redox 
potentials, and concentrations of microelements in different soils in India and Australia. Soil Res. 50, 489-499. doi: 10.1071/SR11266

Yaduvanshi, N., Setter, T., Sharma, S., Singh, K., and Kulshreshtha, N. (2014). Influence of waterlogging on yield of wheat (Triticum aestivum), redox potentials, and concentrations of microelements in different soils in India and Australia. Soil Res. 50, 489-499. doi: 10.1071/SR11266

Ylivainio, K., Jauhiainen, L., Uusitalo, R., and Turtola, E. (2018). Waterlogging severely retards $\mathrm{P}$ use efficiency of spring barley (Hordeum vulgare). J. Agron. Crop Sci. 204, 74-85. doi: 10.1111/jac.12241

Ylivainio, K., Uusitalo, R., and Turtola, E. (2008). Meat bone meal and fox manure as $\mathrm{P}$ sources for ryegrass (Lolium multiflorum) grown on a limed soil. Nutr. Cycling Agroecosyst. 81, 267-278. doi: 10.1007/s10705-007-9162-y

Yordanova, R., Uzunova, A., and Popova, L. (2005). Effects of short-term soil flooding on stomata behaviour and leaf gas exchange in barley plants. Biol. Plant. 49, 317-319. doi: 10.1007/s10535-005-7319-6

Yu, Q., Shen, Y., Wang, Q., Wang, X., Fan, L., Wang, Y., et al. (2019). Light deficiency and waterlogging affect chlorophyll metabolism and photosynthesis in Magnolia sinostellata. Trees 33, 11-22. doi: 10.1007/s00468018-1753-5

Zhang, H., Turner, N., Poole, M., and Simpson, N. (2006). Crop production in the high rainfall zones of southern Australia-potential, constraints and opportunities. Aust. J. Exp. Agric. 46, 1035-1049. doi: 10.1071/ EA05150

Zhang, H., Turner, N. C., and Poole, M. L. (2004). Yield of wheat and canola in the high rainfall zone of south-western Australia in years with and without a transient perched water table. Aust. J. Agric. Res. 55, 461-470. doi: 10.1071/ AR03122

Zhang, J., and Zhang, X. (1994). Can early wilting of old leaves account for much of the ABA accumulation in flooded pea plants? J. Exp. Bot. 45, 1335-1342. doi: $10.1093 / \mathrm{jxb} / 45.9 .1335$

Zhang, S. (2005). Soil Hydraulic Properties and Water Balance Under Various Soil Management Regimes on the Loess Plateau, China. Ph.D. thesis, Swedish University of Agricultural Sciences, Umeå.
Zhang, X., Shabala, S., Koutoulis, A., Shabala, L., Johnson, P., Hayes, D., et al. (2015). Waterlogging tolerance in barley is associated with faster aerenchyma formation in adventitious roots. Plant Soil 394, 355-372. doi: 10.1007/s11104015-2536- $z$

Zhang, X. C., Fan, Y., Shabala, S., Koutoulis, A., Shabala, L., Johnson, P., et al. (2017). A new major-effect QTL for waterlogging tolerance in wild barley $(\mathrm{H}$. spontaneum). Theor. Appl. Genet. 130, 1559-1568. doi: 10.1007/s00122-0172910-8

Zheng, W., Liu, Z., Zhang, M., Shi, Y., Zhu, Q., Sun, Y., et al. (2017). Improving crop yields, nitrogen use efficiencies, and profits by using mixtures of coated controlled-released and uncoated urea in a wheatmaize system. Field Crops Res. 205, 106-115. doi: 10.1016/j.fcr.2017. 02.009

Zhou, M. (2010). "Improvement of plant waterlogging tolerance," in Waterlogging Signalling and Tolerance In Plants, eds S. Shabala and S. Mancuso (Berlin: Springer), 267-285.

Zhou, M., Li, H., and Mendham, N. (2007). Combining ability of waterlogging tolerance in barley. Crop Sci. 47, 278-284. doi: 10.2135/cropsci2006.02.0065

Zhou, M. X. (2011). Accurate phenotyping reveals better QTL for waterlogging tolerance in barley. Plant Breed. 130, 203-208. doi: 10.1111/j.1439-0523.2010. 01792.x

Conflict of Interest Statement: The authors declare that the research was conducted in the absence of any commercial or financial relationships that could be construed as a potential conflict of interest.

Copyright (c) 2019 Manik, Pengilley, Dean, Field, Shabala and Zhou. This is an open-access article distributed under the terms of the Creative Commons Attribution License (CC BY). The use, distribution or reproduction in other forums is permitted, provided the original author(s) and the copyright owner(s) are credited and that the original publication in this journal is cited, in accordance with accepted academic practice. No use, distribution or reproduction is permitted which does not comply with these terms. 